\title{
Regulation and Distrust
}

Philippe Aghion ${ }^{1}$, Yann Algan ${ }^{2}$, Pierre Cahuc ${ }^{3}$ and Andrei Shleifer ${ }^{4}$

July 3, 2008

\footnotetext{
${ }^{1}$ Harvard University, paghion@fas.harvard.edu ${ }^{2}$ Paris School of Economics, yann.algan@ens.fr ${ }^{3}$ Ecole Polytechnique, CREST, cahuc@ensae.fr

${ }^{4}$ Harvard University, shleifer@fas.harvard.edu
} 


\section{Introduction}

In a cross-section of countries, government regulation is strongly negatively correlated with social capital. We document, and try to explain, this highly significant empirical correlation. The correlation works for a range of measures of social capital, from trust in others to trust in corporations and political institutions, as well as for a range of measures of regulation, from product markets, to labor markets, to judicial procedures.

We present a simple model explaining this correlation. The model turns on the idea that investment in social capital makes people both more productive and more civic (e.g., Coleman 1990). Compared to people who have invested in social capital, those who have not are both less productive and impose a negative externality on others when they produce (e.g., pollute). The community (whether through voting or through some other political mechanism) regulates production when the expected negative externalities are large. But regulation itself must be implemented by government officials, who are corrupt if they have not invested in social capital. As a consequence, when production is restricted through regulation, investment in social capital may not pay off. In this model, when people expect to live in a civil community, they expect low levels of regulation, and so invest in social capital. Their beliefs are justified, and investment leads to civility, low regulation, and high output. When in contrast people expect to live in an uncivil community, they do not invest in social capital and remain uncivil and unproductive. Their beliefs again are justified, as lack of investment leads to incivility, high regulation, high corruption, and low production. The model has two Pareto ranked equilibria.

The model explains the correlation between regulation and distrust, but also has a number of additional implications, which we bring to the data. The model predicts, most immediately, that distrust influences not just regulation itself, but the demand for regulation. Using the World Values Survey, we show both in a cross-section of countries, and in a sample of individuals from around the world, that distrust fuels support for government control over the economy. What is perhaps most interesting about this finding, and also consistent with the model's predictions, is that distrust generates demand for regulation even when people realize that the government is corrupt and ineffective; they prefer state control to unbridled production by uncivil firms.

The most fundamental implication of the model, however, is that culture (as measured by distrust) and institutions (as measured by regulation) coevolve. Culture shapes institutions, and institutions shape culture. The causality runs in both directions. Unfortunately, it is very difficult to test this prediction of the model using instrumental variables, since many exogenous factors that influence trust might also directly influence regulation, and vice versa. For example, one can think of using legal origins as instruments for regulation (see, e.g., Djankov et al. 2002, 
La Porta et al. 2008), but to the extent that colonizing Europeans who transplanted legal traditions also transplanted aspects of culture, the instrument would not be valid. We take the evidence on the demand for regulation as supportive of causality running from distrust to regulation. To test the reverse causality, we look at the experiment of transition from socialism, which we interpret as a radical reduction in government regulation in low trust societies. Our model predicts that such a reduction should lead to 1) a reduction in output, 2) an increase in corruption, 3) an increase in demand for government control at a given level of trust, and 4) a reduction in trust in the short run. Some of these predictions are known to be true in the data, we present some evidence supporting the others.

Although our paper combines ideas about regulation and distrust in an apparently novel way, it follows a large literature on related topics. Following Banfield (1958), Gambetta (1988) and Coleman (1990), Putnam (1993) reinvigorated research on social capital by showing tremendous dispersion of levels of trust and social capital across Italian regions as well as the ability of social capital measures to predict government performance. Knack and Keefer (1997) and La Porta et al. (1997) are early empirical studies showing that social capital predicts good economic outcomes in a cross-section of countries. Recent studies in a related vein are Alesina and Glaeser (2004), Guiso, Sapienza, and Zingales (2004, 2006), Tabellini (2005), and Bloom et al. (2007). Landes (1998), La Porta et al. (1997, 1999), Guiso et al. (2003), and Stulz and Williamson (2003) measure culture using religious affiliations, and also examine its effects on outcomes, whereas Licht et al.(2003) introduce psychological measures of culture.

Three recent strands in research have further advanced this area. First, Tabellini (2007a) and Guiso, Sapienza, and Zingales (2007a) present new evidence of deep historical roots of modern variation of trust among regions of Europe and Italy, consistent with Putnam's view that trust is a measure of highly persistent culture. Second, and more closely related to the current paper, Bisin and Verdier (2001), Tabellini (2007b), and Guiso, Sapienza and Zingales (2007b) focus on explicit cultural transmission of beliefs within families, which is in part shaped by economic incentives. Guiso et al. (2006) and Algan and Cahuc (2007) offer empirical evidence consistent with these models using data on second-generation Americans. These papers, however, do not note the connection between distrust and regulation, nor the role of regulation in undermining social capital accumulation.

A second literature intimately related to our work deals with the political demand for regulation and government control more generally. Glaeser and Shleifer (2003) follow the large historical literature on the rise of the regulatory state in the US at the beginning of the 20th century to argue that the demand for regulation results from perceived unfairness of the existing social order. Djankov et al. (2003b) elaborate this reasoning. Di Tella and McCulloch 
(2006) argue that that voters in developing countries disclike capitalism because it is associated with high levels of corruption. Landier et al. (2007) similarly examine cultural attitudes to capitalism.

A third literature has begun to make the point that the causal link runs not only from beliefs to policies but from policies to beliefs as well. Alesina and Angeletos (2005a) describe large variation in beliefs about redistribution across European countries, and show how these beliefs influence, and are influenced by, actual redisribution policies. Alesina and Angeletos (2005b) show how redistribution leads to corruption, which in turn generates demand for redistribution. Aghion, Algan and Cahuc (2008) show that minimum wage policies undermine the ability of firms and workers to learn about each others' cooperative attitudes, and that low cooperation in turns creates a demand for wage policies. Finally, Carlin et al. (2007) focus on the example of financial markets, and argue, similarly to our paper, that trust and regulation are substitutes. Our paper is distinguished from this research in two central ways. First, we consider the twoway relationship between cultural attitudes and the role of the government in the economy at a broader level than the previous papers. Second, our model and analysis explain what is perhaps one of the central puzzles in research on political beliefs: why it is that people in countries with bad governments want more government intervention?

Our paper proceeds as follows. In the next section, we present the basic facts on the relationship between regulation and distrust. Section 3 presents our model and its main implications. Section 4 presents the relationship between distrust and attitudes toward the state and markets. Section 5 examines the effect of deregulation on trust by looking at the transition experience. Section 6 looks at the evidence on educational values across countries, as a further test of the model's assumptions. Section 7 concludes.

\section{Basic facts}

This section correlates distrust and government regulation across countries. The exact definitions of variables are summarized in the Appendix.

\subsection{Data on distrust}

We use data on distrust from the World Values Survey (WVS). The WVS database is an international social survey consisting of three main waves 1981-84, 1990-93 and 1999-2003, denoted henceforth 1980, 1990 and 2000. ${ }^{1}$ This survey provides a range of indicators of distrust in others,

\footnotetext{
${ }^{1}$ The World Value Survey also provides a wave in 1995 but for a smaller set of countries and questions.
} 
in markets, and in institutions for a large sample of countries around the world.

The basic measure of distrust comes from the following question: "Generally speaking, would you say that most people can be trusted or that you need to be very careful in dealing with people?". We construct a distrust indicator equal to 0 if the respondent answers "Most people can be trusted" and 1 if she answers "Can't be too careful". We take the average country-level of distrust over the three waves 1980, 1990 and 2000.

We also use indicators of distrust associated with the lack of civic spirit. As stressed by Glaeser et al. (2000), the question about trust may capture trustworthiness of others rather than trust in others. We use the following question from the World Value Survey: "Do you think that it is unjustifiable to cheat on government benefits?". The answer ranges from 1 for "never justifiable" to 10 for "always justifiable". We define the proportion of uncivic households as those who do not think that it is never justifiable to cheat on public benefits.

Distrust can be measured not only with respect to other people but also as confidence in business, in unions, and in the legal and political system. We consider the following set of questions provided by the WVS : "Do you have a lot of confidence, quite a lot of confidence, not very much confidence, no confidence at all in the following : Major Companies? Unions? Justice? Parliamentary democracy?". The answers range from 1 for a lot of confidence, to 2 for quite a lot of confidence, to 3 for a little confidence, to 4 for no confidence. We create a 1-0 dummy which is equal to 1 if the respondent chooses the answer no confidence, and zero otherwise. We thus have four dummy variables distrust in companies, distrust in organized labor, distrust in legal system, and distrust in political system.

\subsection{Data on regulation}

To measure regulation, we start with government regulation of the product market. We use Djankov et al. (2002) data on the number of steps that an entrepreneur must complete to open a business legally. The measure is available for the year 1999 and covers almost all countries present in the WVS database. We also use an index of the frequency of price controls by the state. Gwartney et al. (1996) construct an index of the extent to which companies can set prices freely, from 0 for no freedom at all to 10 for perfect freedom. La Porta et al. (2002) use the average of this index for the two available years 1989 and 1994 as a measure of price controls.

Next, we look at the regulation of the labor market. Botero et al. (2004) construct an index of the rigidity of employment regulation that aggregates three areas: i) Difficulty of hiring, ii) Rigidity of hours, and iii) Difficulty of firing. The sub-index of hiring difficulty measures the availability of temporary and alternative contracts. The sub-index of hours rigidity measures the 
legal maximum number of hours, and restrictions over evening hours, and minimum vacations. The sub-index of firing rigidity measures the legal procedures, such as advanced notice, required to terminate a job. We also use a measure of the extent of state regulation of the minimum wage, which takes into account the existence of a statutory legal minimum wage and the potential exceptions based on age, skills, industries, or regions. This index is from Aghion et al. (2008) and covers 21 OECD countries. We also look at formalism of legal procedures from Djankov et al. (2003a).

Using these data, we can estimate the empirical relationship between distrust and regulation for a maximum of 56 countries. The list includes: Argentina, Australia, Austria, Belgium, Brazil, Bulgaria, Canada, Chile, China, Colombia, Croatia, Czech Republic, Denmark, Dominican Republic, Egypt, Finland, France, Germany, Greece, Hungary, India, Indonesia, Ireland, Italy, Jordan, Japan, Korea, Latvia, Lithuania, Morocco, Mexico, Netherlands, Nigeria, Norway, New Zealand, Pakistan, Peru, Philippines, Poland, Portugal, Romania, Russia, Slovakia, Slovenia, Spain, South Africa, Sweden, Switzerland, Taiwan, Turkey, United Kingdom, Ukraine, Uruguay, Vietnam, United States and Venezuela. The sample of countries changes slightly depending on the indicators for distrust and the type of regulation we are looking at.

\subsection{The correlation between distrust and regulation}

We present nine figures illustrating the relationship between distrust and regulation. Figure 1 illustrates the strong positive correlation between the regulation of entry as measured by the (ln)-number of steps to open a business, and the country level of distrust. High-trusting countries such as Nordic and Anglo-Saxon countries impose very few controls for opening a business while low-trusting countries, typically Mediterranean, Latin-American, and African countries, impose heavy regulations. More than one-third of the cross-country variation in the regulation of entry is explained by distrust.

Figure 2 presents the evidence on the correlation between state control of price-setting and country-level distrust. A strong negative correlation shows up between the freedom that firms enjoy in setting their prices and distrust. The $\mathrm{R}^{2}$ is also around 0.34 .

Figure 3 and 4 present the relationship between regulation of the labor market and distrust. Figure 3 reports the correlation between the rigidity of employment contracts and distrust. A strong positive correlation shows up between this indicator and distrust. Nordic countries such as Finland, Norway, and Sweden are outliers in this figure. Yet, when we focus on state regulation of the minimum wage, these Nordic countries fit much more with the other high-trusting countries such as Denmark or Anglo-Saxon countries. Figure 4 shows that the correlation between state regulation of the minimum wage and the country-level of distrust is strongly positive; 65 percent 


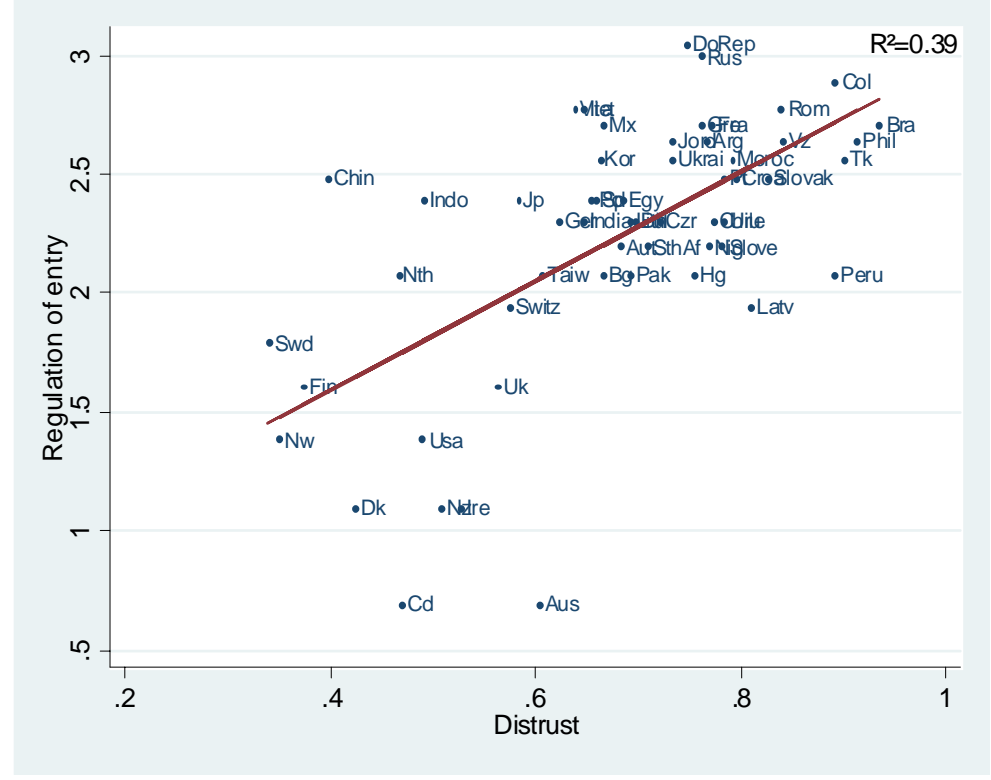

Figure 1: Distrust and Regulation of entry. Regulation is measured by the (ln)-number of procedures to open a firm. Sources: World Value Survey and Djankov et al. (2002).

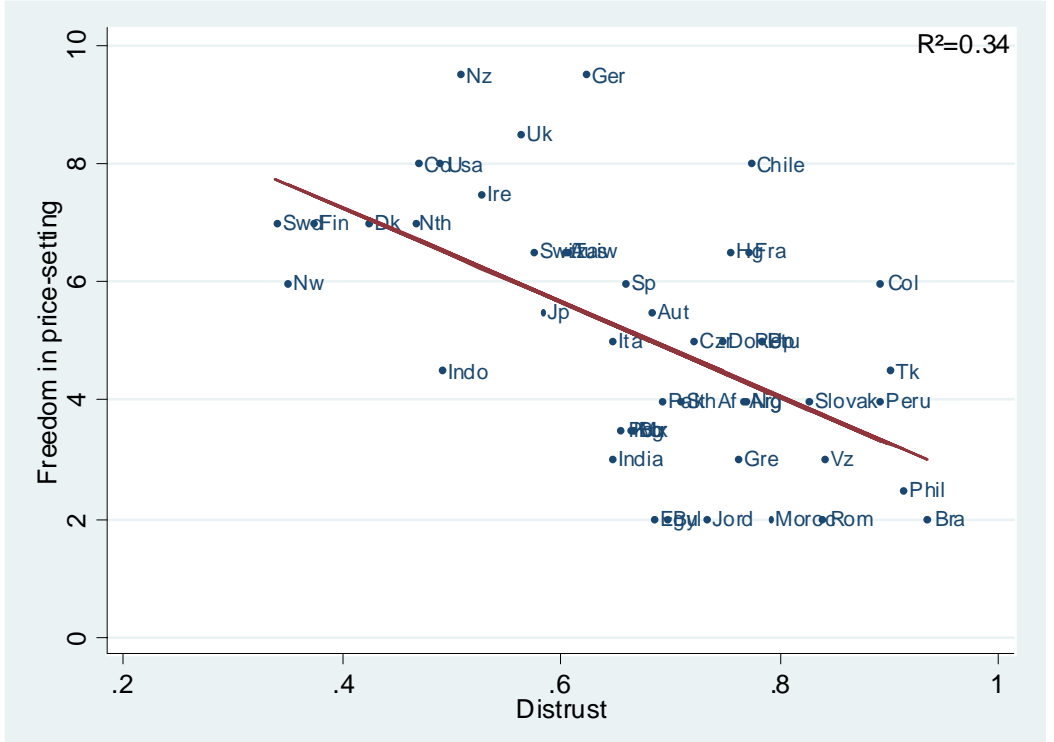

Figure 2: Distrust and Freedom of firms in setting prices. The indicator ranges from 1 for no freedom at all to 10 for perfect freedom. Source: WVS database and La Porta et al. (2002). 
of the variance in distrust is explained by state regulation of wages.

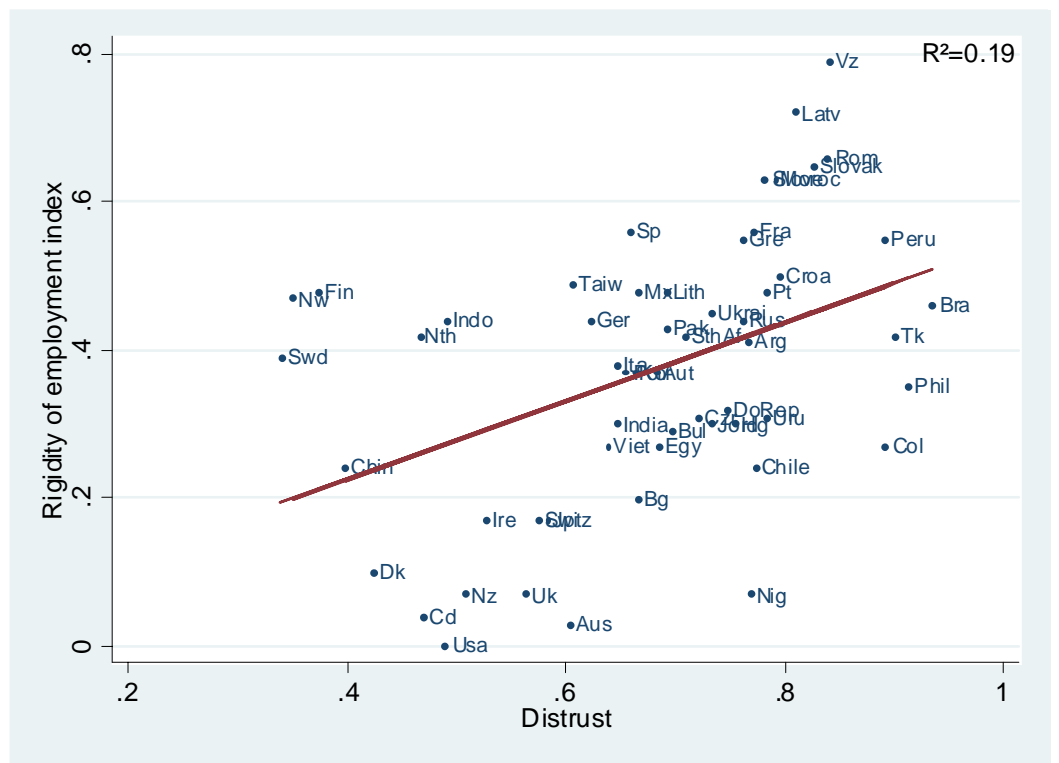

Figure 3: Distrust and Rigidity of employment index. Sources: World Value Survey and Botero et al. (2004).

Figure 5 shows that the same relationship holds between distrust and judicial formalism. High-trusting countries have less judicial formalism.

Figures 6 through 9 show the correlation between entry regulation and distrust of big companies, of unions, of parliament, and of the legal system, respectively. The figures reveal a strong positive correlation between the (ln)-number of procedures to open a business and distrust. The most significant relation shows up for distrust of companies, of the parliament and of the legal system, the $\mathrm{R}^{2}$ reaching $.22, .23$ and .33 percent, respectively.

Tables 1 and 2 confirm these correlations in regressions controlling for the log per capita GDP and education. The correlation between the extent of regulation of markets and distrust in others or distrust in institutions is statistically significant at the one percent level in most cases. In contrast, per capita income does not predict regulation while the effect of education is less statistically significant compared to distrust. 


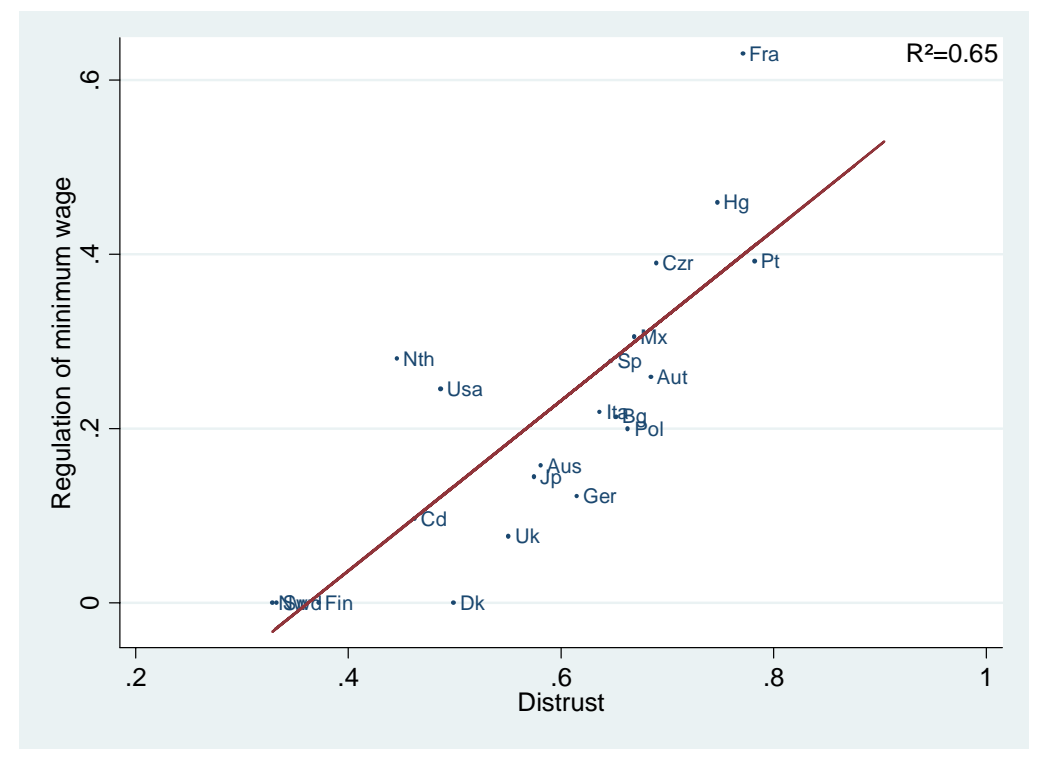

Figure 4: Distrust and State regulation of minimum wages. Source: WVS database and Aghion, Algan, Cahuc (2008).

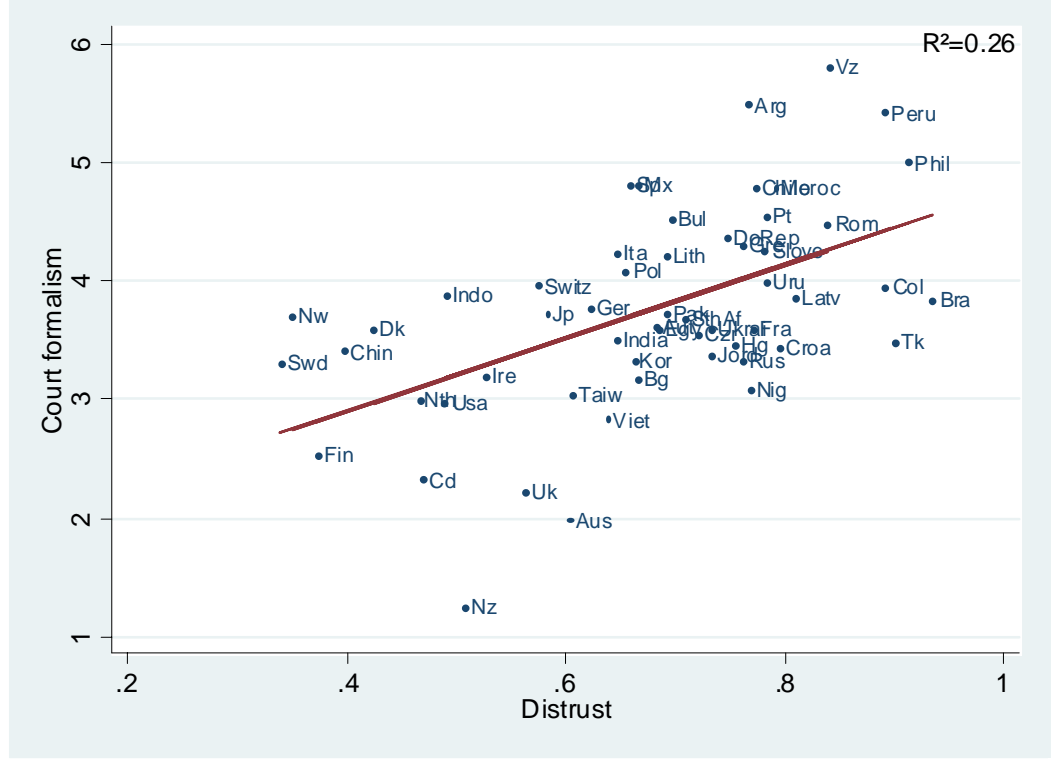

Figure 5: Distrust and Court formalism. The index measures substantive and procedural statutory intervention in judicial cases at lower-level civil trial courts in a case for evicting a tenant that has not paid rent. Higher values represent more statutory control or intervention in the judicial process. Source: Djankov et al. (2003a). 


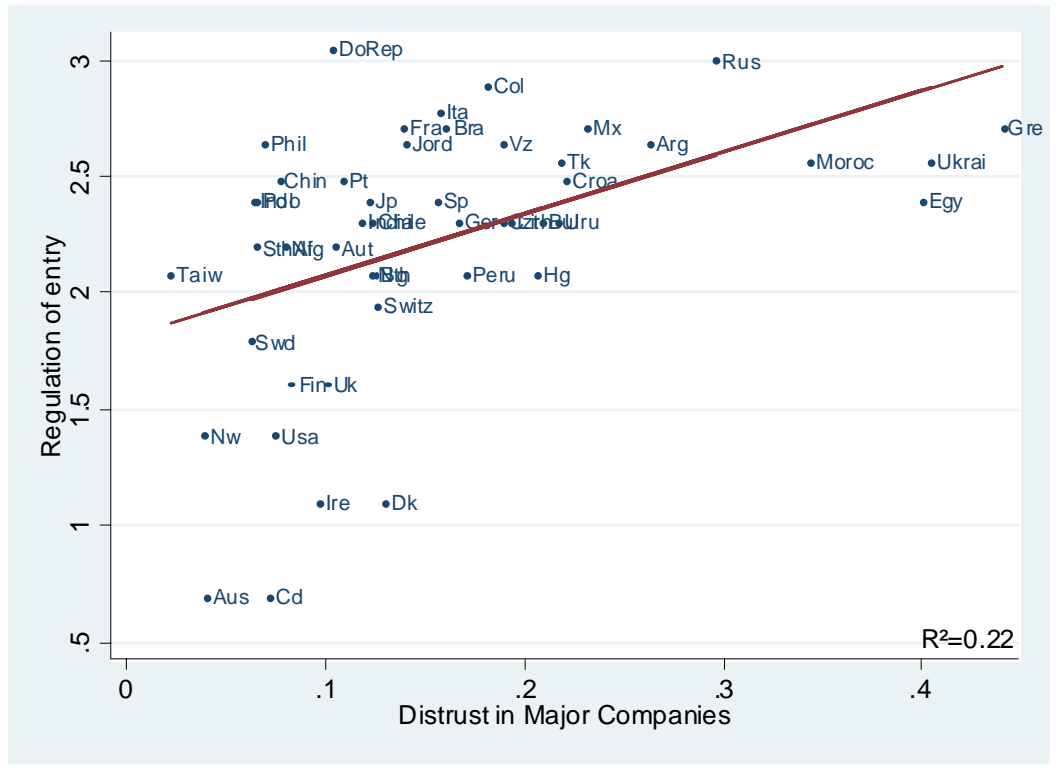

Figure 6: Distrust in Major Companies and regulation of entry. Regulation is measured by the (ln)-number of procedures to open a firm. Sources: World Value Survey and Djankov et al. (2002).

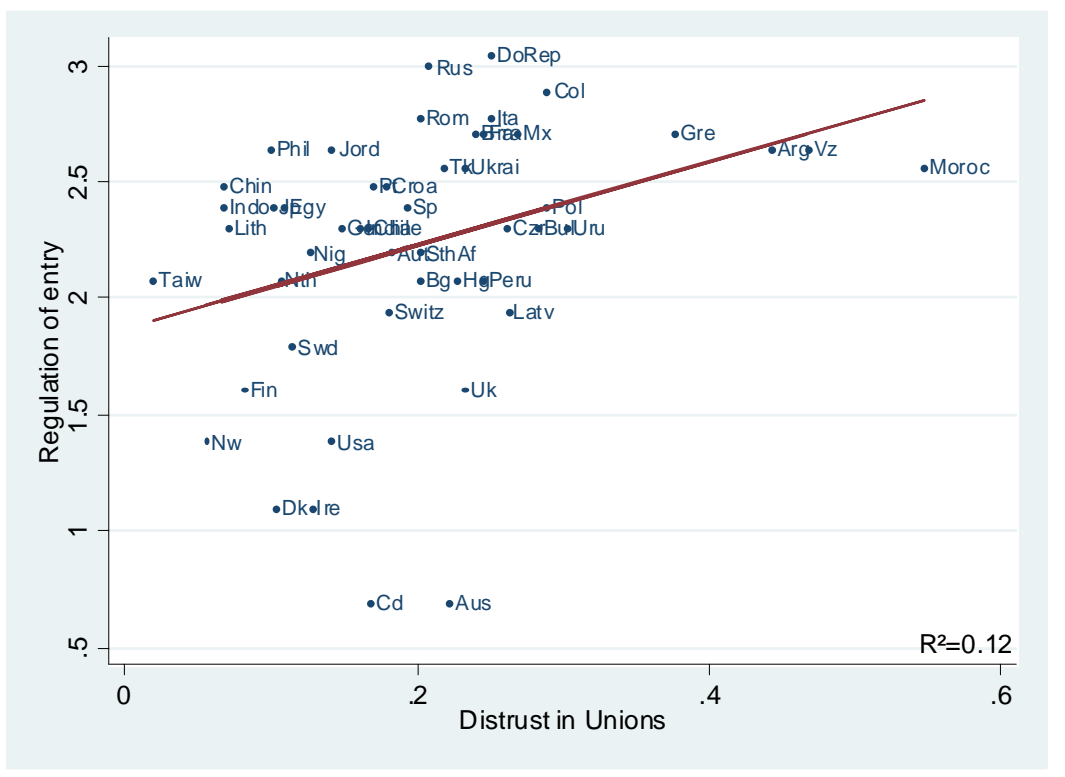

Figure 7: Distrust in unions and regulation of entry. Regulation is measured by the (ln)-number of procedures to open a firm. Sources: World Value Survey and Djankov et al. (2002). 


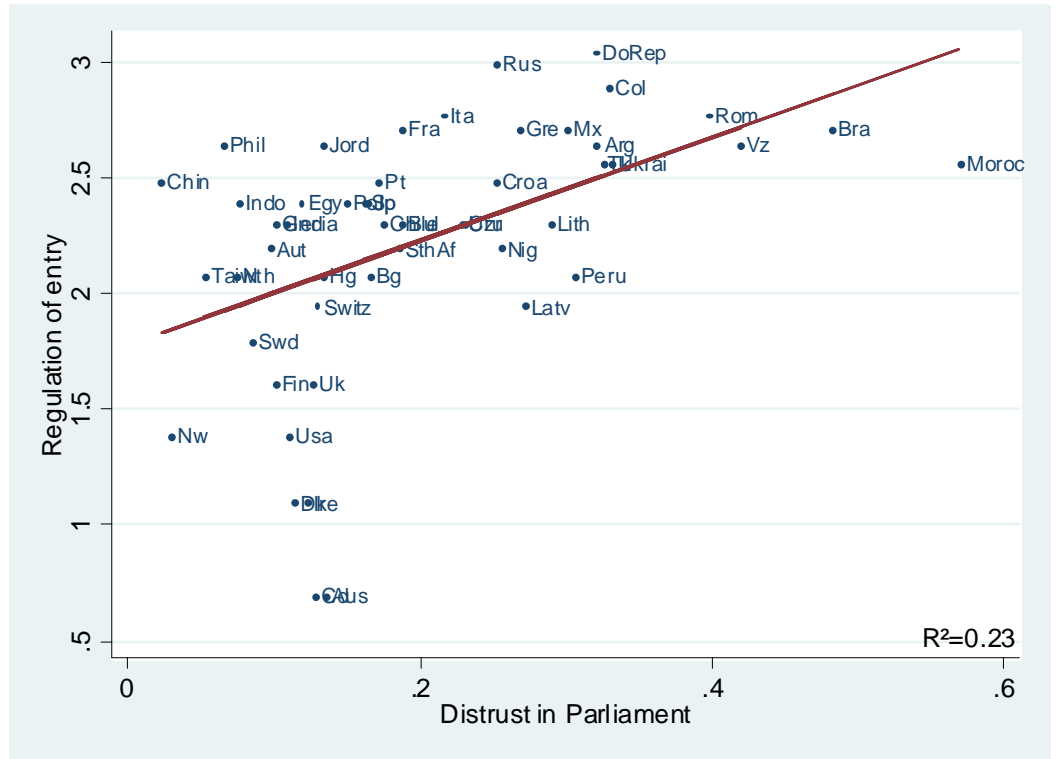

Figure 8: Distrust in Parliament and regulation of entry. Sources: World Value Survey and Djankov et al. (2002).

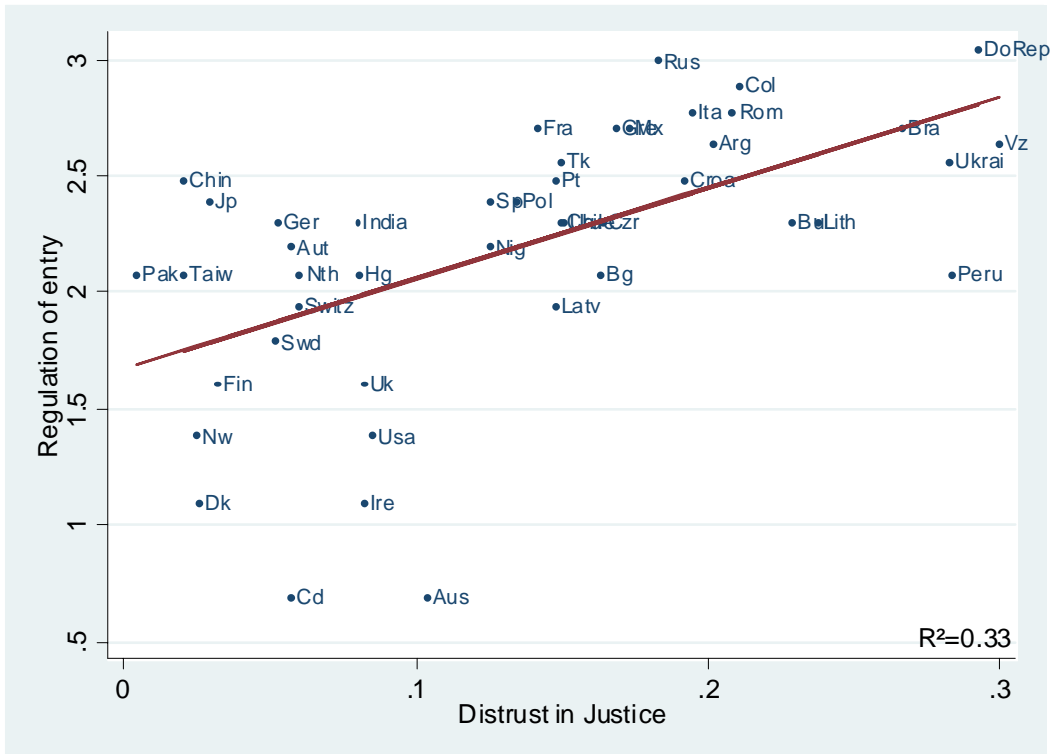

Figure 9: Distrust in justice and regulation of entry. Sources: World Value Survey and Djankov et al. (2002). 
We have also checked the effects of democracy and ethnic fractionalization (Easterly and Levine 1997, Alesina and Ferrara 2002, Alesina et al. 2003). Ethnic fractionalization is measured by the ethnolinguistic fragmentation variable of Easterly and Levine (1997). Democracy is measured by the average Polity IV score over for the period 1980-2000. Table 3 reports these robustness checks for the relationship between the (ln) number of steps to open a business and the various indicators of distrust. The correlation between regulation and distrust remains statistically significant, while fractionalization and democracy do not have any effect. 


\section{The model}

We present a simple model that highlights the interplay between distrust and regulation, with causality running in both directions. When individuals distrust others, they fear a negative externality from the others' actions. They thus call for heavier public regulation, restricting entry into productive activities. But regulation is implemented by public officials, who demand bribes when they themselves are not civic. Regulation and corruption then deter investment in social capital in the first place, which may lead to a self-fullfilling high regulation low social capital equilibrium.

We consider an economy in which the society chooses whether or not to regulate productive activities that can generate negative externalities, but requires officials to implement these regulations. Each individual can decide whether or not to invest in social capital. We generally think of this investment being made in families, but recognize that schooling as well can be designed to have a large social capital component (Glaeser, Ponzetto, and Shleifer 2007). The key assumption is that there cannot be investment in social capital coordinated by the society. Individuals who invest in social capital are productive and do not impose negative externalities on others when they produce. They also do not take bribes when serving as officials. Individuals who do not invest in social capital are less productive but also impose negative externalities on others; they are also corrupt when serving as officials. We can think of the negative externalities in production as pollution that affects the whole community.

Consider the model and its timing in more detail. There is a continuum of risk neutral individuals of mass one. There are two goods: labor and numeraire good produced with labor. The timing of events is as follows:

1. Individuals can either invest a fixed amount $i>0$ in social capital or not invest at all. If they invest, they become civil; otherwise they are uncivil. Uncivic individuals produce $y$ units of the numeraire good. $y$ is uniformly distributed on the interval $[0,1] . y$ is private information. Uncivil individuals generate a negative externality which costs $e$ per capita. Civil individuals do not generate a negative externality when they produce. They produce output $y$ that they would get if they did not invest, plus an additional $k>0$. The only reason we assume a positive private return to investment in social capital is to create private incentives to make that investment. Denote by $\alpha$ the fraction of the population that invests in social capital.

2. People vote to regulate entry into productive activity or to leave it unrestricted (alternatively, public authorities maximize social welfare). We assume that the society does not have the option to stop all productive activity, but rather must rely on officials to implement the regulation. The regulatory rule takes the following (plausible) form: a person may produce only 
if his output net of the externality is positive. However, officials do not observe either the individual's output $y$ or whether he has invested in social capital.

3. Individuals produce if production is authorized. Officials, like individuals more generally, can be either civil or uncivil. We assume that officials are drawn randomly from the population (alternatively, people work as officials at night), so there is no decision of becoming a producer or an official (this can lead to interesting complications - see Murphy et al. (1991)). If an official is civil, he implements the regulatory rule, which given his information set means that he forbids entry. If an official is not civil, he uses his power as the implementer of the rule to demand a bribe to authorize production regardless of the producer's type. We denote by $b$ the bribe demanded by uncivil officials. We assume for simplicity that civil producers refuse to pay bribes and abstain from production when encountering a demand for a bribe, but uncivil producers pay the bribe if it is rational for them to do so and produce. We can alternatively assume that all officials demand bribes, or that all producers pay them when they are demanded. Recall that since investment in social capital is private information, it is impossible to forbid the production by the civil and to authorize that by the uncivil.

We make the following two assumptions: (1) investment in social capital has positive private returns if the productive activity is authorized:

$$
k>i
$$

and (2) the social returns of the production of any uncivil person are negative

$$
e>1 \text {. }
$$

Before solving the model, a preliminary remark is in order. We could have had a much simpler model in which there are no government officials or corruption. Regulation takes the simple form of prohibiting all production. In that model, there would still be multiple Pareto ranked equilibria: a good one with high social capital and low regulation, and a bad one with low social capital and high regulation. Such a model would deliver the positive relationship between distrust and regulation. That simple model, however, leaves unsettled one of the central issues in the data, namely why it is the case that individuals who distrust government nonetheless want more government intervention. By introducing public officials into the model, we are able to address this issue and to generate testable predictions. We should also note, in this regard, that

there are many ways to introduce corrupt public officials into the model: the central subsantive assumption is that such officials through their actions reduce both negative externalities and the incentives to invest in social capital. 
We solve the model by backward induction. In the third step, all individuals produce if production is unregulated or authorized in step 2. In equilibrium, if individuals expect no regulation, then everyone invests in social capital, since it earns positive private returns. We need to figure out what happens with regulation.

If the society decides to regulate production in step 2, every uncivil official sets the bribe that maximizes his rent, equal to the bribe times the share of individuals who agree to pay it

$$
b(1-b)(1-\alpha) .
$$

This optimization problem reflects the two facts that a) only the uncivil agree to pay bribes and b) among them, only those with productivity above the level of the bribe actually pay it. The term $(1-b)$ comes then from the assumption that $y$ is uniformly distributed on $[0,1]$. With these assumptions, the optimal bribe chosen by uncivil officials is equal to $1 / 2$.

We can now compute the social decision to regulate, as a function of the fraction of the community who have invested in social capital, $\alpha$. Without regulation, the expected output (since everyone produces) is given by:

$$
A=\frac{1}{2}+\alpha k-(1-\alpha) e,
$$

where the first term is output without investment in social capital, the second term is the incremental output from investment in social capital, and the third term is the aggregate externality.

If the society chooses to regulate, then the expected output is given by:

$$
R=(1-\alpha)^{2} \int_{1 / 2}^{1}(y-e) \mathrm{d} y=\frac{(1-\alpha)^{2}}{2}\left(\frac{3}{4}-e\right) .
$$

To understand this expression, note that all civil officials prohibit production since they are not sure that the producer is civil, and that when civil producers encounter uncivil officials, they refuse to pay bribes, and there is no production either. Production only occurs when uncivil producers encounter uncivil officials, and pay bribes (there is the double coincidence of incivility). Moreover, it is only the most productive uncivil producers who are able to pay the bribe, so they produce and impose negative externalities on others. Since we have assumed that the per captia externality $e$ is larger than 1 , social output $R$ under regulation is necessarily negative. Note that, in this model, social output is normalized to be zero if all private activity is outright forbidden by law, since then people do not produce but also do not impose externalities on others. We can think of this scenario as state ownership or state dominance of the economy, which leaves no room for either private initiative or bureaucratic discretion.

As shown by Figure 10, there exists a unique threshold value of $\alpha \in(0,1)$, denoted by $\alpha^{*}$, such that $A>R$ if and only if $\alpha>\alpha^{*}$. 


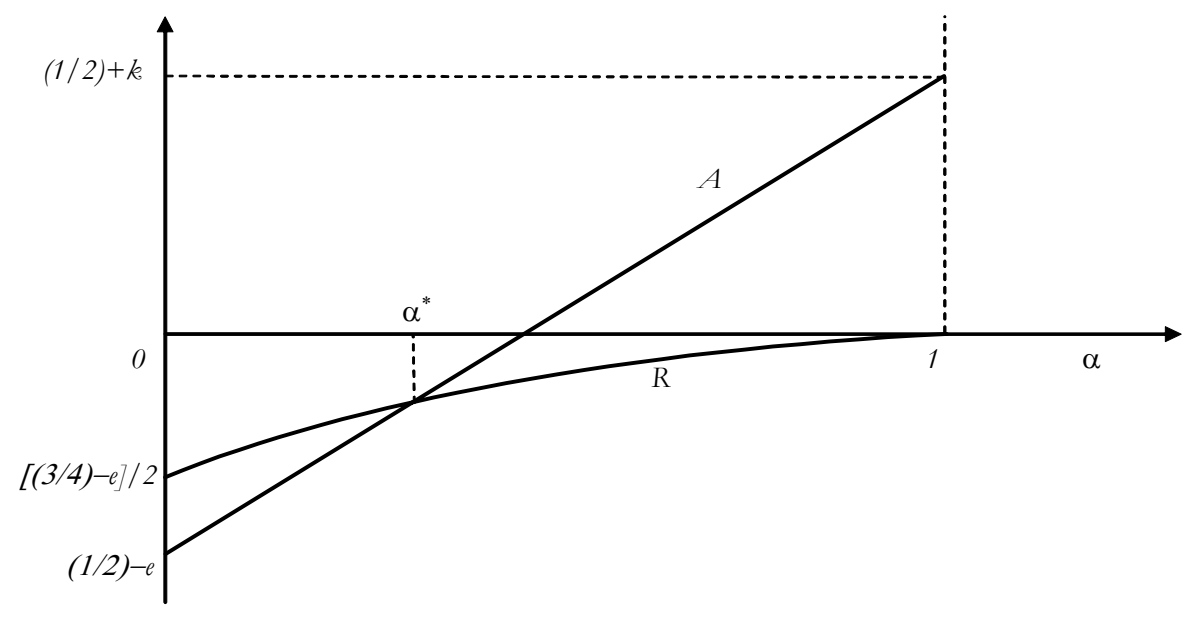

Figure 10: The threshold value $\alpha^{*}$ above which regulation yields lower social welfare than the authorization of production.

We can use this figure to understand the incentives to invest in social capital, as a function of expectations about regulation. In the first step, if $\alpha<\alpha^{*}$, the best reply for an individual is not to invest because he anticipates that production will be regulated, which implies that the net returns to investment in social capital are negative, since individuals who invest in social capital never produce in a regulated regime (they are not allowed to produce by civil officials and refuse to pay bribes to the uncivil ones). When $\alpha>\alpha^{*}$, the best reply for each individual, in contrast, is to invest because he expects production not to be regulated, and his private returns to investment are high. This implies that there are two stable equilibria.

1. Everybody invests in social capital $(\alpha=1)$ and it is optimal for the society to authorize unregulated productive activity. There is no room for corruption since there is no regulation and consequently no officials.

2. Nobody invest in social capital $(\alpha=0)$. In this equilibirum, productive activity is regulated, and should ideally be forbidden, but uncivil officials allow some individuals to produce against the payment of bribes. The production of those who pay bribes entails negative externalities, so social output in this equilibrium is actually negative.

The first equilibrium clearly dominates the second since social welfare is equal to $(1 / 2)+k>0$ in the equilibrium with investment in social capital and to $\left(\frac{3}{4}-e\right) / 2<0$ in the equilibrium without such investment. There are no other stable equilibria.

The two equilibria have very intuitive interpretations. In the good equilibrium, levels of social capital are high, individuals do not expect others to impose negative externalities on them or the society, and hence they do not see any reason to regulate activity. Social capital eliminates 
the demand for regulation. In turn, since activity is unregulated and returns to investment in social capital are high, individuals make the investment. As a consequence, output is at the maximum possible level in this economy.

In the second equilibrium, in contrast, there are no benefits to investment in social capital since producers are either stopped by civil regulators or held up by bribe-takers. (Even if we assume that individuals who invest in social capital are willing to pay bribes, there will be a bad equilibrium at a low $\alpha$, since it is still the case that regulation either forbids or discourages production). Interestingly, in this second equilibrium, even though the regulators who allow production are corrupt, they still serve a useful social purpose since, with the society being largely uncivil, the negative externalities from production outweigh the positive benefits. The society would be even worse off without the regulation, if all uncivil individuals were allowed to produce. This observation creates an interesting paradox in our model. Specifically, even though the regulators are corrupt, the society wants more regulation and further restrictions on production - it wants more government control. To return to Figure 10, they want output to be closer to the horizontal line at zero. Production by uncivil producers is so bad that it is better to have more restrictions on them, whether this means state management or more regulation. When individuals distrust others, they prefer government officials to regulate and control, even when they know that these officials themselves cannot be trusted.

This simple model has three interesting implications. First, if we intepret the model as suggesting that different countries are at different equilibria, the model explains our starting fact. Specifically, high-trust societies exhibit low levels of government regulation, and low-trust socieities exhibit high levels of government regulation.

Second, perhaps more subtly, the model suggests that distrust drives the demand for regulation. In low trust societies, individuals correctly do not trust business, since business is dishonest. To control business, they support government regulation, fully recognizing that such regulation leads to corruption. Furthermore, individuals in low trust societies want to have even more government control than they see already, since more control would weed out even more producers imposing negative externalities. The model thus predicts the demand for more regulation even when regulation is very ineffective, and for more government even when the government is corrupt. We test this prediction below. However, we here note the important relationship to the work of DiTella and McCulloch (2006), who argue that corruption leads to leftist politics and the demand for more government. The authors do not explain the paradox of how corrupt government leads to the demand for more government, but our model explains why. Individuals rationally demand more government, even more of corrupt government, when they see private business as imposing large negative externalities. 


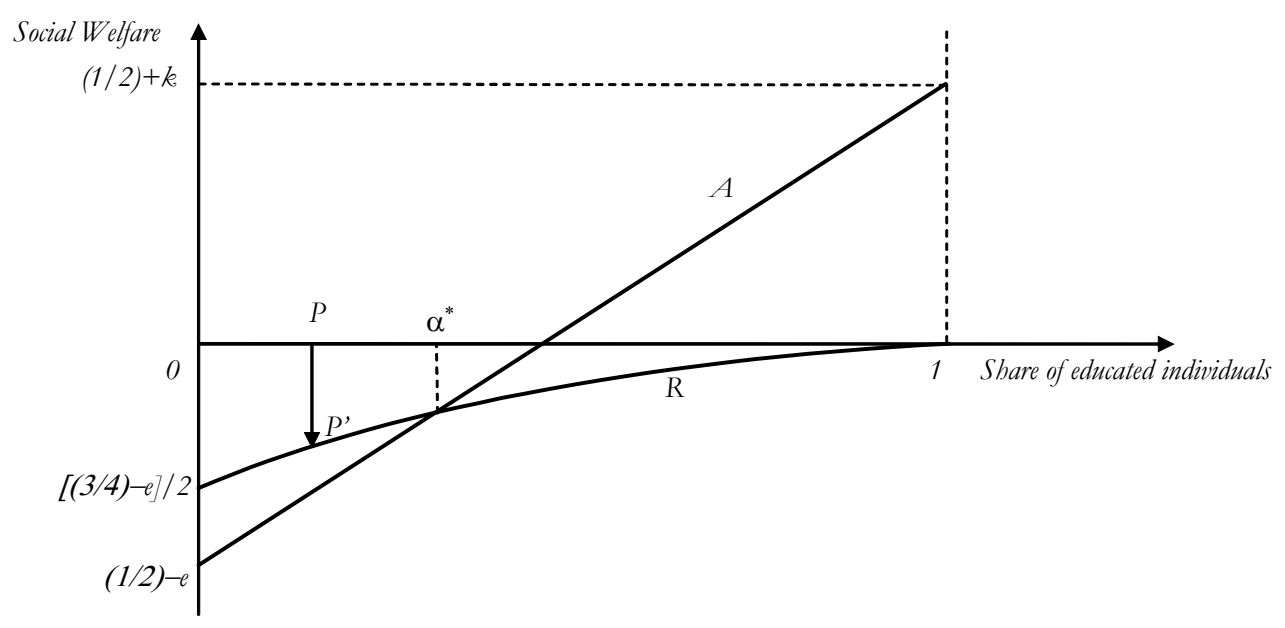

Figure 11:

Third, our model has some implications for the causal effect of regulation on accumulation of social capital. Suppose we start in an environment with low social capital and very high levels of state control. For instance, suppose we start with a point on the horizontal line in the figure, and then move to the $R$ curve. Figure 11 describes the situation in which the economy starts from a very low $\alpha$ corresponding to socialism (point $\mathrm{P}$ ), and then the drop of that point to the R-curve after liberalization (point $\mathrm{P}^{\prime}$ ).

If that happens, the model predicts that output falls and corruption rises. It also predicts that people would demand more regulation - a return to the point where activity is largely controlled by the state. Perhaps most interestingly, the model predicts that, starting from this disequilibrium, people will reduce their investment in social capital, and trust in others and in institutions will diminish. Unless social capital is built up, the economy moves toward the bad equilibrium. We assess this set of predictions using the experience of transition from socialism.

\section{The Effect of Distrust on the Demand for Regulation}

\subsection{Data}

In this section, we seek to establish three points related to the first implication of the model. These are: 1) the political demand for regulation varies across countries, 2) countries that have a higher demand for regulation actually have higher regulation, and, most importantly, 3) low trust predicts high demand for regulation, and not just high actual levels of regulation. We thus hope to suggest, as predicted by the model, that there is a causal link from distrust to 
regulation working through popular demand.

We use the four waves of the World Values Survey (WVS) and different waves from the International Social Survey Program to measure attitudes towards regulation.

The WVS database has already been presented above and we focus on the same set of countries. The World Values Survey database contains three main questions concerning attitudes toward competition or state regulation. The first question reads : "Competition is good. It stimulates people to work hard and develop new ideas or Competition is harmful. It brings out the worst in people". The variable takes on values from 1 to 10, a lower score indicating a higher level of distrust of competition. The second question reads: "People should take more responsibility to provide for themselves or the government should take more responsibility". The variable ranges from 1 to 10, with a higher score indicating a stronger support for government intervention. In addition to these questions, we also look at a question related to the efficiency of the economic system under democracy: "Here are some things that people sometimes say about a democratic political system: In democracy, the economic system runs necessarily badly. Could you please tell me if you agree strongly, agree, disagree or disagree strongly?". To make the result more interpretable, we create a dummy variable equal to 1 if the respondent strongly agrees or agrees with the statement that the economy runs badly under democracy.

The ISSP database is a compilation of surveys devoted each year to different specific topics such as religion, social networks or the role of the government. It has been carried out since 1985. Two specific ISSP surveys on "The role of government" were carried on in 1990 and 1996. These surveys ask five specific questions about regulation. The first two questions assess the views of regulation of wages and prices: "Here is a list of potential government action for the economy: i) Control prices by law, ii) Control wages by law". The answer can take on values from 1 to 4 , with 1 meaning strongly agree and 4 strongly disagree. To ease the interpretation of the results, we create two dummy variables for control of wage and price by grouping together households who strongly agree or agree with such a government intervention. Three other questions refer to government control of specific sectors: "Do you think that electricity should be run by the government or private companies? Hospital should be run by the government or private companies? Bank should be run by the government or private companies?". In 1996 the answers take on the value 1 to indicate that the sector should be run by the government and zero otherwise.

The ISSP surveys on government regulation cover almost all OECD and East European countries. Moreover, the ISSP database contains separate surveys for East and West Germany. By merging the two waves 1990 and 1996, we get observations for the following list of 8 East 
European countries: Bulgaria, Czech Republic, Hungary, Latvia, Poland, Romania, Russia, Slovenia, in addition to East Germany. We also have information for the following 19 OECD countries: Austria, Canada, Denmark, Finland, France, West Germany, Ireland, Italy, Japan, Netherlands, Norway, New Zealand, Norway, Portugal, Spain, Sweden, Switzerland, United Kingdom and United States. The panel of countries is unbalanced between 1990 and 1996.

\subsection{Public support for regulation}

Figures 12 through 16 display attitudes toward government regulation at the country level, based on the ISSP database. Figures 12 and 13 report the share of households who strongly agree or agree with the statement that the government should control wages and prices. We measure the country average over the two ISSP surveys in 1990 and in 1996. Former socialist countries such as Russia, Slovenia, East Germany and Bulgaria exhibit the strongest support for government control of wages. Approximately 92 percent of Russians and 79 percent of East Germans favor wage control. Respondents in Mediterranean countries such as France, Italy and Spain also strongly favor wage control by the state: 76 percent of the Spaniards and 60 percent of the French agree with the statement. At the other extreme we find Anglo-Saxon and Nordic countries such as Sweden, and to a lesser extent Norway. In these countries, no more than one third of the households agree with the statement that the government should control wages.

Figure 13 provides a similar picture of attitudes toward government control of prices. Respondents in the former socialist and the Mediterranean countries strongly agree or agree with the idea that the government should control prices, while those in Anglo-Saxon and Nordic countries are less in favor of it. The differences among countries are even starker when we only focus on the share of households who strongly agree that government should control prices rather than just agree. Figure 14 shows that 60 percent of Russian, 52 percent of East German and 46 percent of French respondents strongly agree with the need for government control of prices. This share drops to 22 percent in Sweden, 16 percent in Norway and United Kingdom, and 10 percent in the United States. Figures 15 and 16 display the share of households who think that electricity and banks should be mainly run by the government, calculated at the country level in 1996. The ranking of countries is broadly consistent with the previous indicators. A similar picture holds for the different indictors of regulation provided by the WVS database, discussed in the next section.

Figures 17 and 18 show the correlation between political support for regulation and the objective measures of actual regulation of the goods and labor markets. We use the (ln) number of steps to open a business and the rigidity of employment index as indicators of actual regulation. The correlation between the subjective measure of political support for regulation and the 


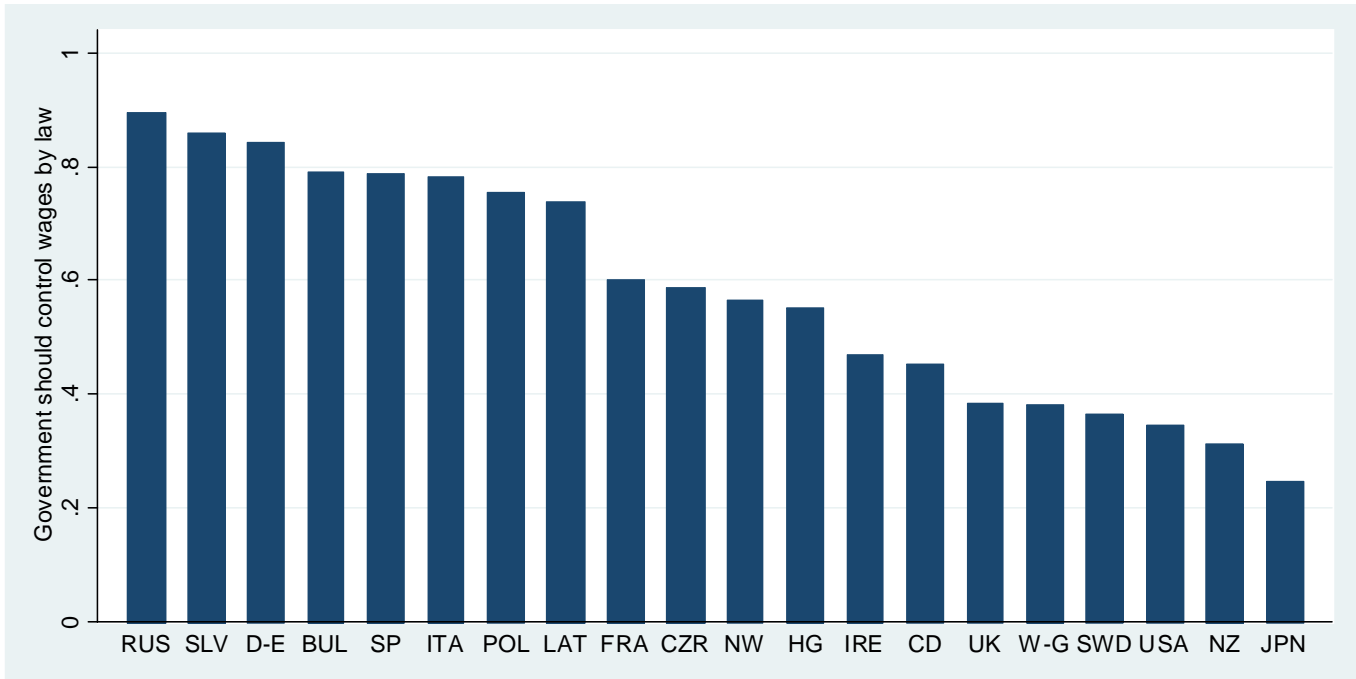

Figure 12: Share of political support for wage control by law. Source: ISPP 1990-1996

objective measures of regulation is fairly high, the $\mathrm{R}^{2}$ reaching 0.37 for the goods market and 0.39 percent for the labor market. This result suggests that understanding regulation requires understanding the determinants of its political support. We present this analysis below.

\subsection{Distrust and public support for regulation}

One of the central implications of the model is that distrust causes support for regulation. In this section, we look at this relationship.

We begin with simple correlations. Figure 19 through Figure 21 present the correlations at the country-level between distrust in others and support for government control of prices and of specific sectors such as electricity. The indicator of distrust is based on the 4 waves of the WVS database. The support for government control is given by the indicators of ISSP in 1990 and 1996. The correlation between distrust and support for regulation is always positive and significant, the R-squared reaching 0.33 for wage control, 0.16 for price control and 0.20 for government control of electricity.

Table 4 reports the corresponding micro evidence. We regress the various measures of political support for regulation on distrust in others and distrust in public institutions. The left hand side variables are indicators of regulation preferences and are reported in rows. We control 


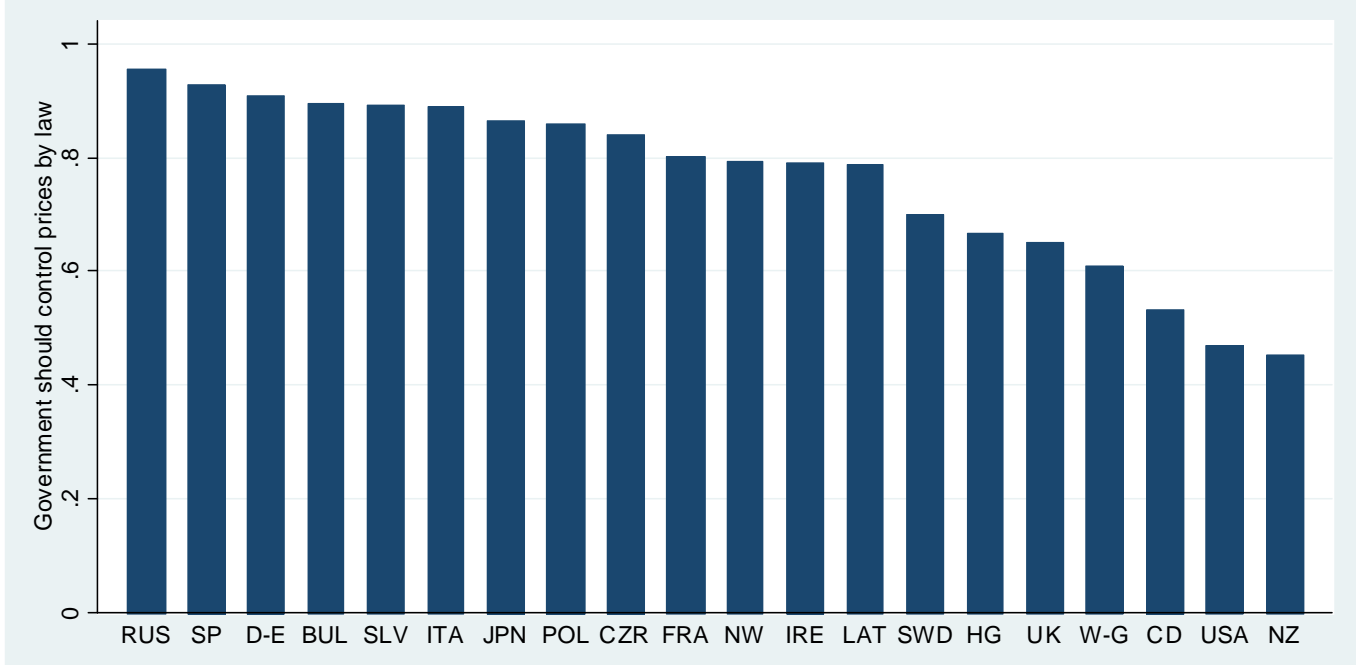

Figure 13: Share of political support for price control by law. Source: ISPP 1990-1996.

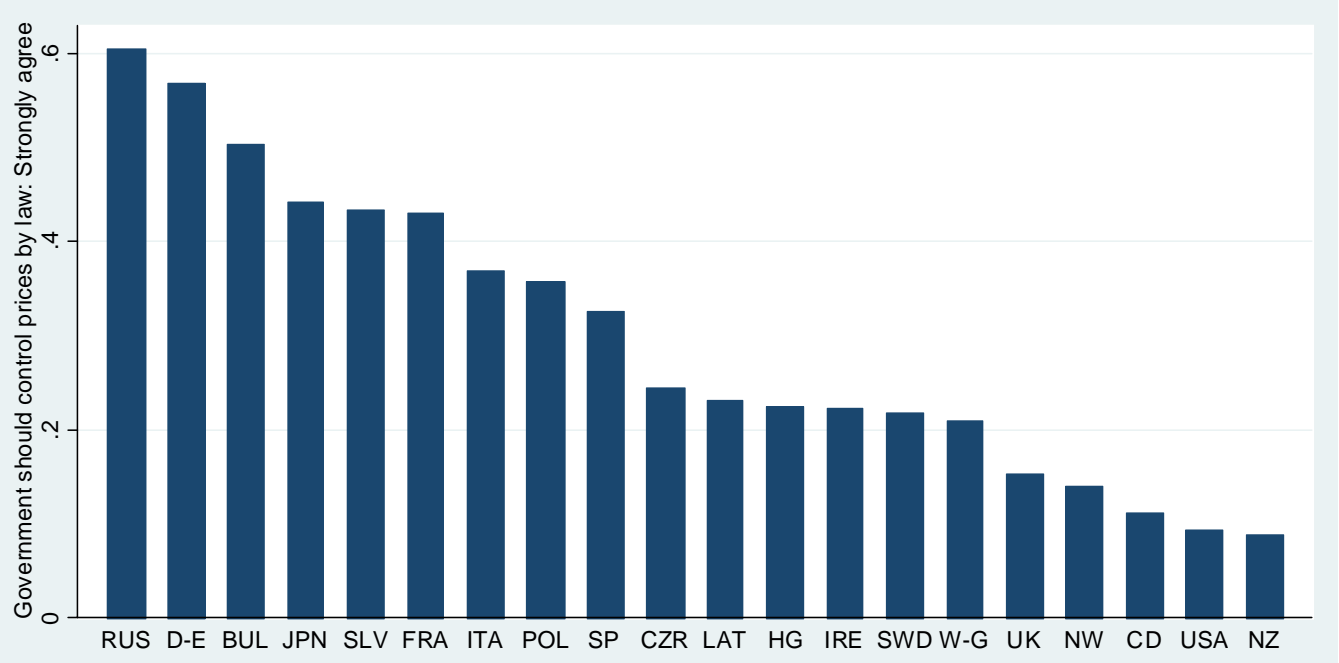

Figure 14: Share of households who strongly agree with price control by law. Source: ISPP 1990-1996 


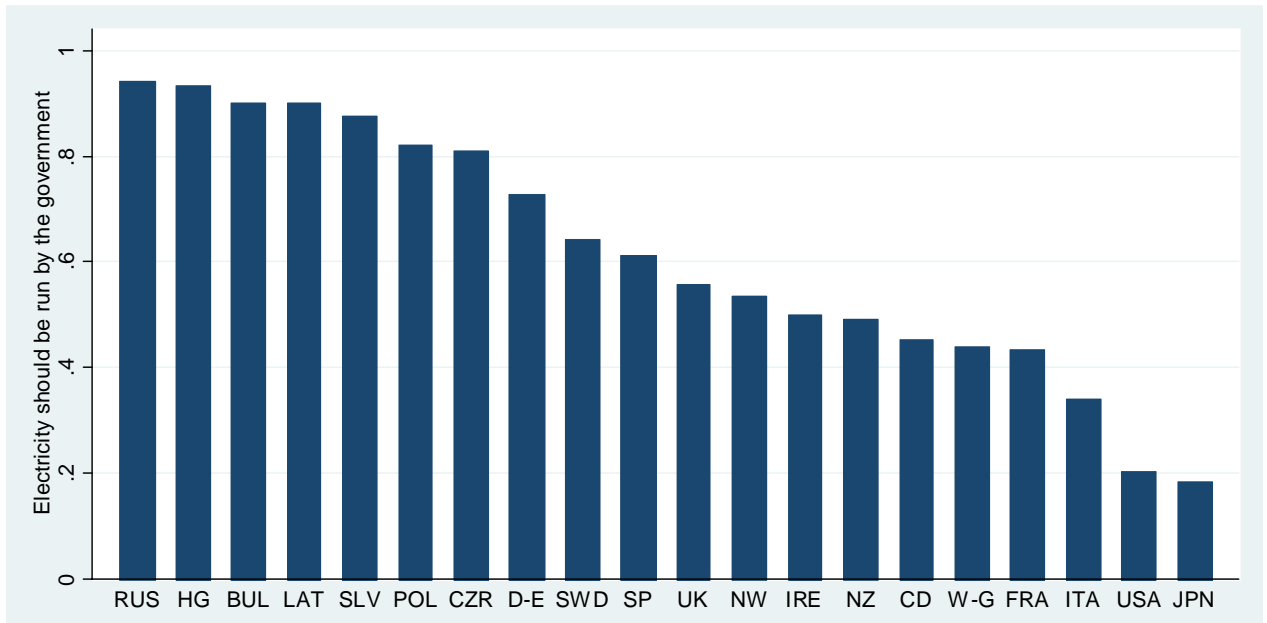

Figure 15: Share of political support for government control of electricity. Source: ISPP 1996

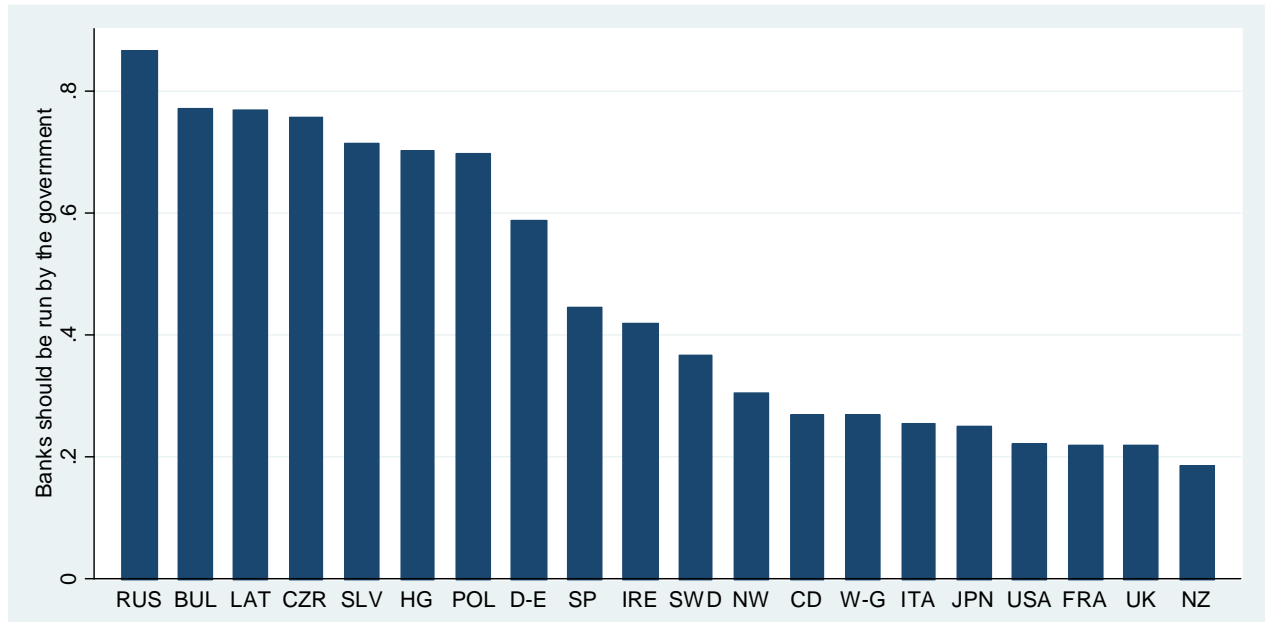

Figure 16: Share of political support for government control of banks. Source: ISPP 1996 


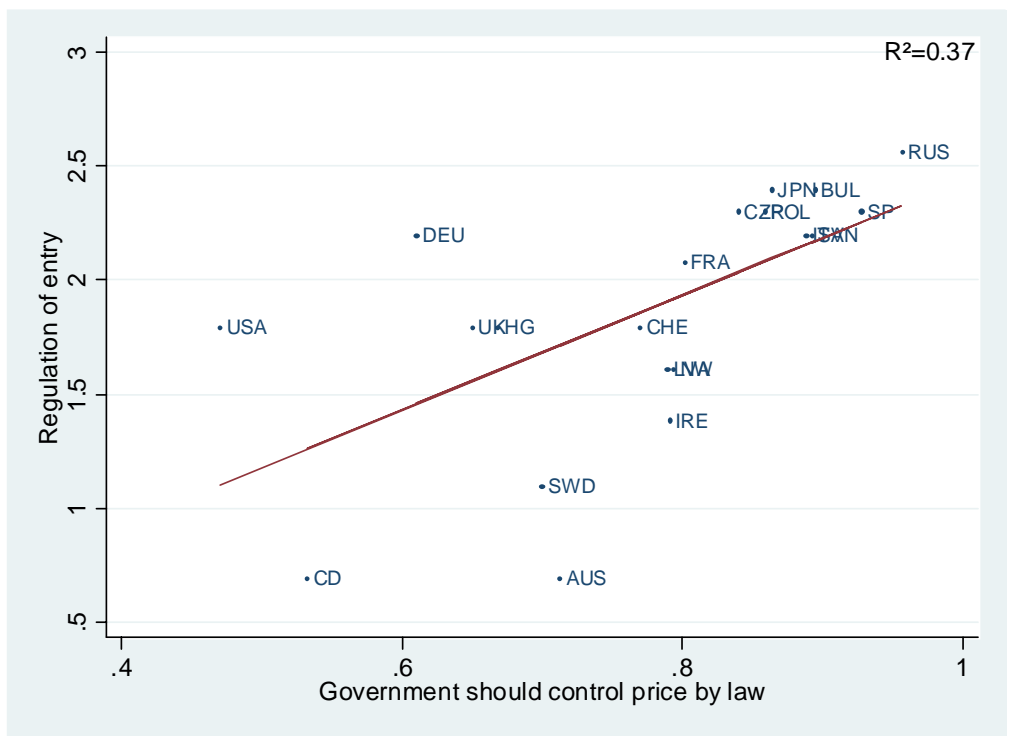

Figure 17: Correlation between regulation of entry and political support for government control of prices. Source: ISSP 1990-1996 and Laporta et al. (2002)

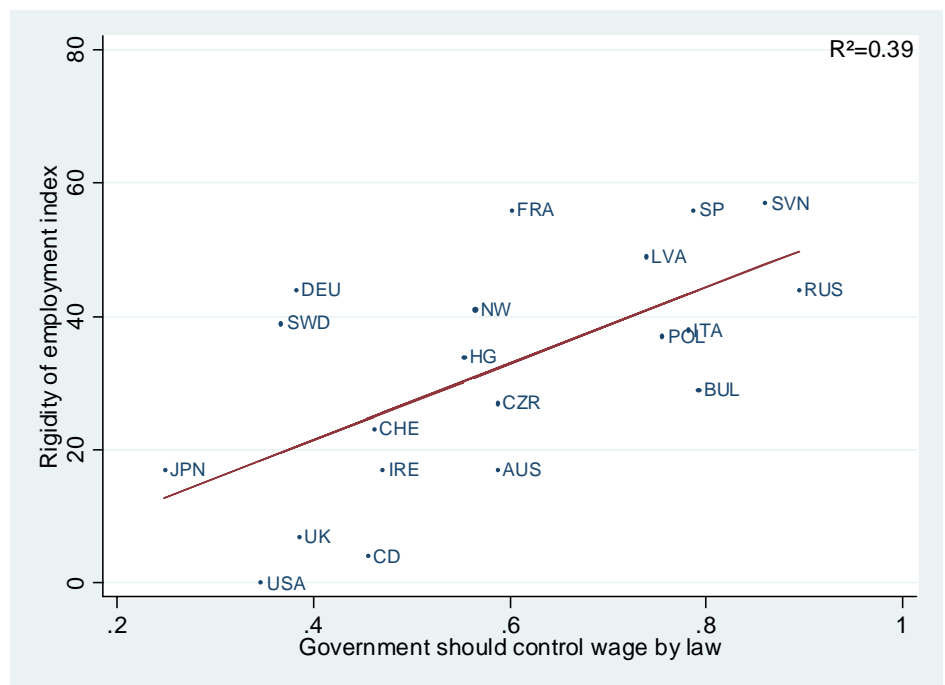

Figure 18: Correlation between rigidity of employment index and political support for government control of wages. Source: ISSP 1990-1996 and Botero et al. (2004) 


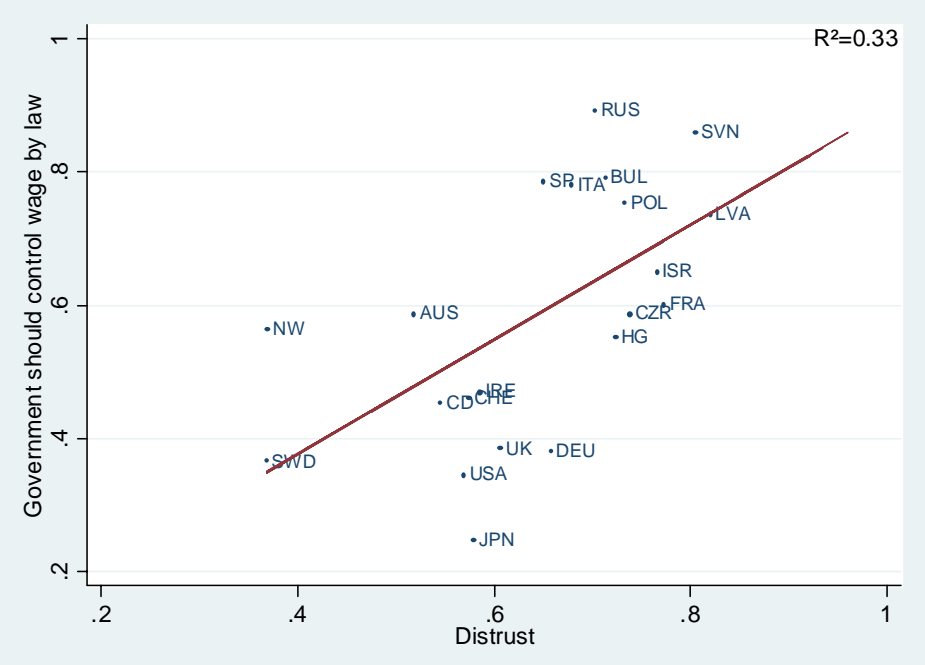

Figure 19: Correlation between distrust and political support for government control of wages. Source WVS: 1980 - 2000 and ISSP 1990 and 1996.

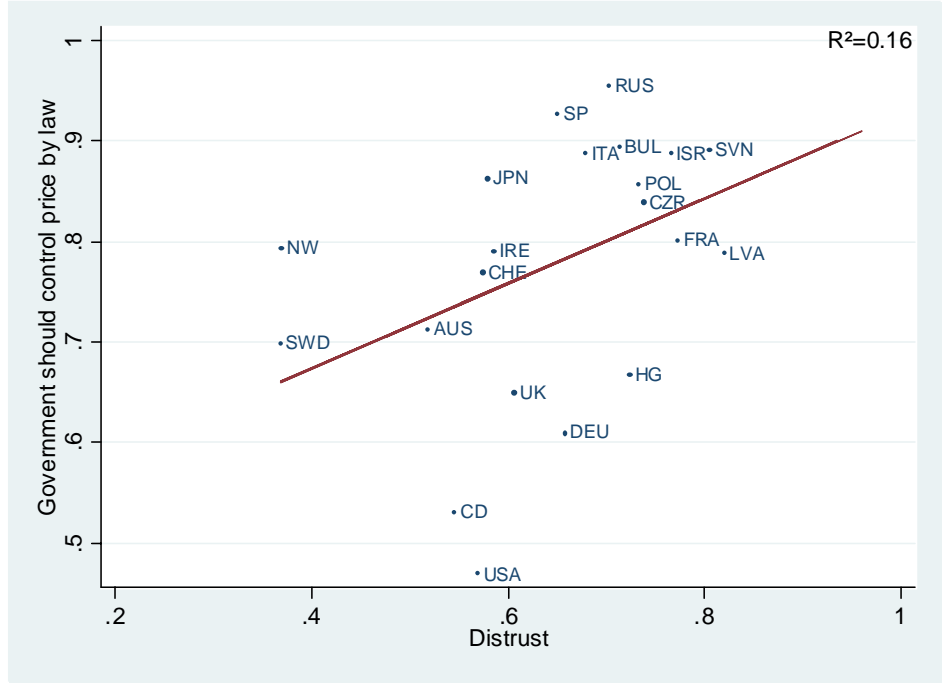

Figure 20: Correlation between distrust and political support for government control of prices. Source WVS: 1980 - 2000 and ISSP 1990 and 1996. 


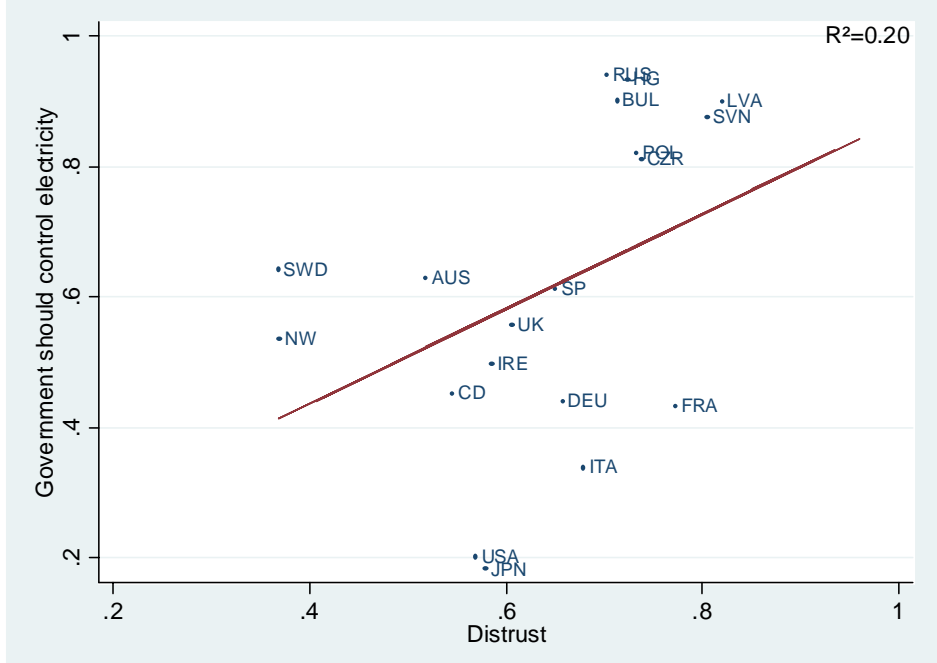

Figure 21: Correlation between distrust and political support for government control of electricity. Source WVS: 1980 - 2000 and ISSP 1996.

for age, gender, education, income and political affiliation. We have also run robustness checks by controlling for the occupation in the public sector, the religious affiliation, and the income per capita of the country, without noticeable change.

Row 1 reports the ordered probit regression for attitudes towards competition. Individuals who distrust others are more likely to believe that competition is harmful. The relationship is statistically significant at the 1 percent level. Individuals who distrust private companies, the legal system, or the civil servants also dislike competition. Row 2 shows that the same distrustful individuals call for more responsibility of the government; the relationship is statistically significant at the 1 percent level. Row 3 shows that the same relationship holds between distrust and the belief that the economic system runs badly under democracy. In the WVS data, distrustful individuals seek greater control by government, consistent with a central prediction of our model.

\section{The effect of regulation on distrust}

Perhaps the more unusual prediction of our model is that regulation itself causes distrust. We have elaborated an implication of this prediction in our model, namely that, in a low trust society, an exogenous liberalization from the position of nearly full state control would cause a decline in output, an increase in disorder and corruption, a demand for re-regulation, and absent such re-regulation an increase in distrust. In this section, we assess this prediction 
in the context of transition economies. Our starting point is the observation that the rapid transition from socialism to capitalism, and the dismantling of the communist party and other control mechanisms of the state (Shleifer 1997) can be seen as reductions of state control from nearly total to something more similar to the regulatory regime in our model. The initial years of transition could then be seen as a sharp reduction in state control. Consistent with the predictions of our model, output initially declined in all transition economies (e.g., Shleifer and Treisman 2005). Corruption has also increased, consistent with the model's predictions. We need to investigate whether the initial levels of trust were low in socialist economies, whether deregulation has caused a demand for re-regulation, and most importantly, whether these events brought about growth in distrust. Below, we focus on these three questions. Our methodology is closely related to Alesina and Fuchs-Schündeln (2007).

\subsection{Initial level of social capital in transition economies}

We begin with a simple description of the initial level of distrust in socialist countries. We have data on the initial level of distrust in transition economies circa 1990, provided by the wave 1990 of the WVS database. We focus on the comparison of transition and OECD economies.

Figure 22 reports the cross-country level of distrust for the 1990 wave. We measure the national component of distrust by estimating the country fixed effects in the individual-level regression of trust on individual characteristics (age, education, gender, income). The country fixed effect is measured relative to Sweden, which displays the lowest level of distrust in this wave. Figure 22 reports the marginal probit estimates of country fixed effects. For instance, Figure 22 shows that, compared to Swedes, Romanians exhibit a 32 percentage points higher probability of distrusting each other. The highest level of distrust in 1990 is in socialist countries.

Table 5 reports marginal probit estimates of the effect of living in a transition economy on different indicators of distrust in 1990. We create a dummy equal to 1 if the country used to be socialist, and 0 if it belongs to the OECD. We control for age, education, gender, income and political affiliation of the respondents.

Table 5 - Column 1 shows that the probability of distrusting others rises by 16.9 percentage points when the respondent is living in a transition rather than an OECD country during the wave 1990. The effect is statistically significant at the 1 percent level. Distrust in civil servants and distrust in justice are also higher by 5.5 percentage points and 6.5 percentage points, respectively, in transition compared to OECD countries. The same pattern holds for distrust in companies. Living in a transition economy increases the probability to distrusting business by 15.5 percentage pionts relative to OECD countries. The effect is statistically significant at the 1 percent level. 


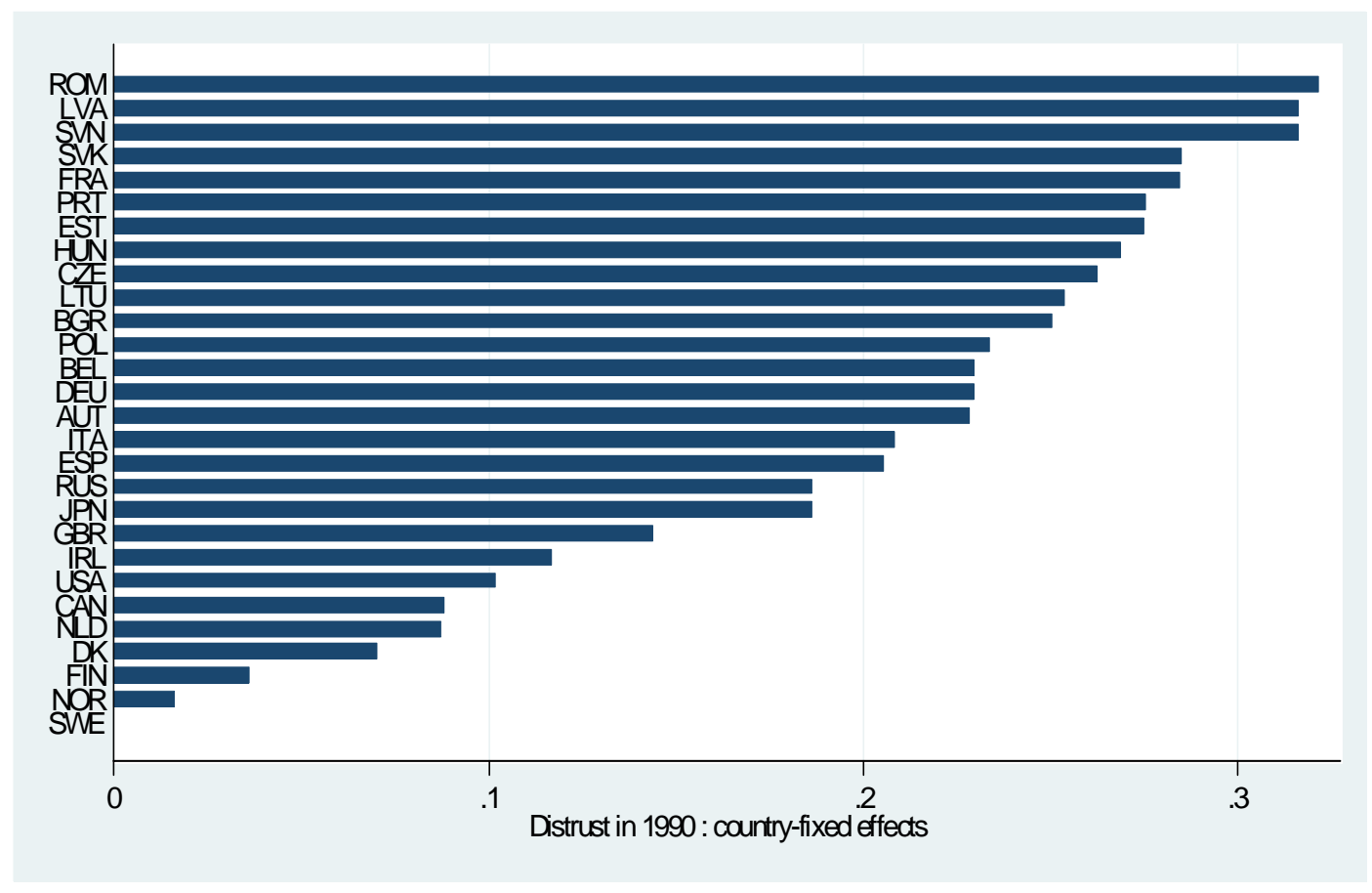

Figure 22: Marginal country fixed effects on distrust relatively to Sweden. Source: WVS 1990.

\subsection{Deregulation and the Demand for Regulation}

What is the effect of deregulation on the demand for government control? Table 6 documents the evolution of the demand for regulation in transition economies, with comparison to OECD countries. We look at two main questions related to regulation provided by the WVS database in 1990 and 2000. The first one is related to attitudes towards competition, already described above. The second one reads as follows: "There is a lot of discussion about how business and industry should be managed. Which of these four statements comes closest to your opinion? Owners should run their business, Owners/Employees participate in selection, Government should be the owner, Employees should own the business". We create a dummy variable equal 1 if the respondent answers "Owners should run their business", and zero otherwise.

The main explanatory variable of interest is the interaction term between the wave 2000 dummy and the dummy for transition economies. The interaction term measures the change in the demand for regulation in transition economies between 1990 and 2000. We also include the wave 2000 dummy without interaction. This dummy measures the change in the demand for regulation in OECD countries. We also include a dummy for transition economies. We control for age, gender, years of education, and income. Additional regressions with political affiliation, 
religious affiliation, and employment status yield similar results, but for fewer observations.

Table 6 reports the estimates. Column 1 shows the ordered probit estimates of attitudes toward competition. The sign of the interaction term between the transition dummy and the wave 2000 is strongly positive and statistically significant at the 1 percent level. This result indicates that distrust of competition has sharply increased in transition economies over this period. The sign associated with the wave 2000, taken separatly, is also positive, suggesting a rise in distrust of free markets in OECD countries too. Yet the effect is much smaller and the Wald test rejects the equality of coefficients.

Column 2 shows the marginal probit estimates concerning private ownership. The difference between transition economies and other OECD countries becomes sharper. The sign on the interaction term between the transition dummy and the wave 2000 is negative, suggesting that individuals in transitions economies have become more opposed to the view that owners should run their businesses. The effect is statistically significant at the 1 percent level. In contrast, the sign of the wave 2000 dummy taken separately is positive, suggesting the reverse evolution of attitudes, in favor of private management, in OECD countries.

\subsection{Liberalization and Change in social capital}

We finally turn to the evolution of social capital in transition economies following liberalization. We begin with simple descriptive figures concerning transition economies. Figures 23 through 24 report the change in distrust between the wave 1990 and the wave 2000. We still compare transition economies with OECD countries. Distrust has increased in some OECD countries as well as in the former socialist countries. In particular, a sharp increase in distrust occurred in Anglo-Saxon countries over this period. Yet some OECD countries have also experienced a fall in distrust. In contrast, all former socialist countries, except Slovenia, have experienced a rise in distrust. An even stronger difference between transition and OECD countries is to be found in the evolution of distrust in civil servants and in private companies, as shown in Figures 24 and 25 .

To assess the consequences of deregulation for distrust in transitions economies more formally, we focus on the two separate waves of the WVS database in 1990 and 2000. The left hand side variables are the indicators of distrust. The main explanatory variable of interest is the interaction term between the wave 2000 dummy and the transition economy dummy. This interaction measures the change in distrust within transition economies. We also include a wave 
2000 dummy taken separately to measure change in distrust in OECD countries. The other baseline controls include age, education, gender, income category, and political affiliation.

Table 7 - Column 1 shows that distrust in others has increased in both transition and OECD countries. But this rise is not statistically significant in OECD countries when we control for country fixed effects and individual characteristics. In contrast, the rise in distrust in transition economies is statistically significant at the 10 percent level. The effect is sizeable: the probability of distrusting others has increased by 5.8 percentage points in transition economies, almost twice as much as the rise in OECD countries.

Table 7 - Column 2 shows that a statistically significant rise in distrust of civil servants has also occurred in transition economies. Individuals living in transition economies are 12.5 percentage points more likely to distrust civil servants in 2000 than in 1990. During the same period, distrust in civil servants has declined by 3 percentage points in OECD countries. The Wald test confirms this contrast. Columns 3 and 4 show that distrust in justice and in business have increased by 8.5 percentage points and 10.5 percentage points, respectively, in transition economies. The increase is statistically significant. Distrust in justice and in business has also increased slightly in OECD countries, but the effect is either not statistically significant in the case of distrust in justice or the rise is economically much lower in the case of distrust in business. The Wald test rejects the equality of coefficients between transition economies and OECD countries.

\section{Parental Values and Distrust}

As a final piece of evidence, we go back to the central element of our model that accounts for the perpetuation of both culture and institutions, namely parental investments in social capital of their children. In our model, regulation crowds out the incentives to invest in social capital, including feelings of responsibility and respect of others. In this case, parents seek to transmit respect for authority rather than develop feelings of responsibility and tolerance.

We use the following 2 questions in the World Values Survey: "Here is a list of qualities which children can be encouraged to learn at home. Which, if any, do you consider to be especially important: Independence? Tolerance and Respect for other". The variable takes on the value 1 if the respondent mentions the quality and 0 otherwise. The respondent can mention several values to transmit to the children. We create two dummies Educ_Independence and Educ_Tolerance that are equal to 1 if the respondent mentions the quality and 0 otherwise. 


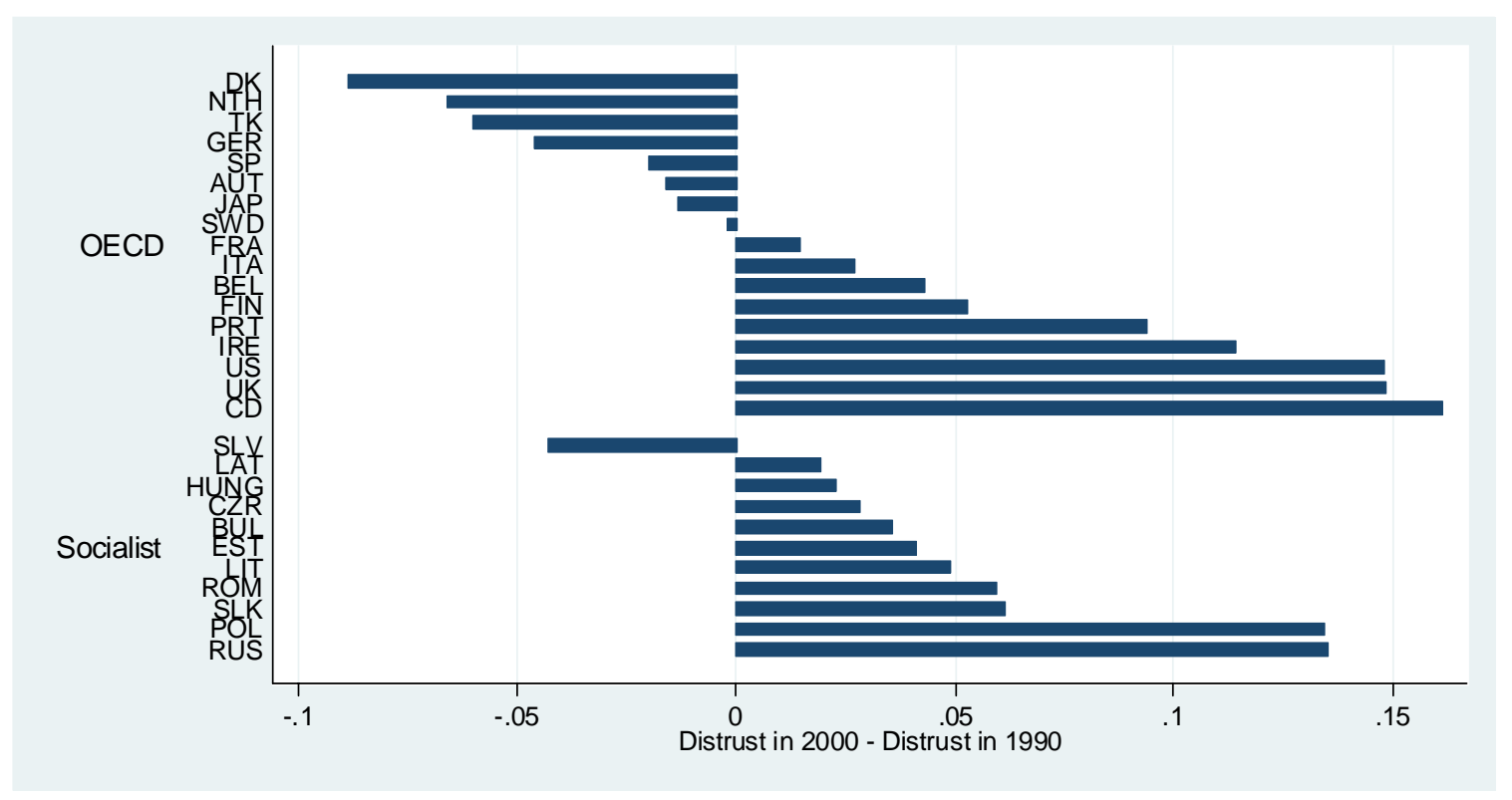

Figure 23: Time-variation in the share of households who distrust others between the waves 2000 and 1990. Source WVS database.

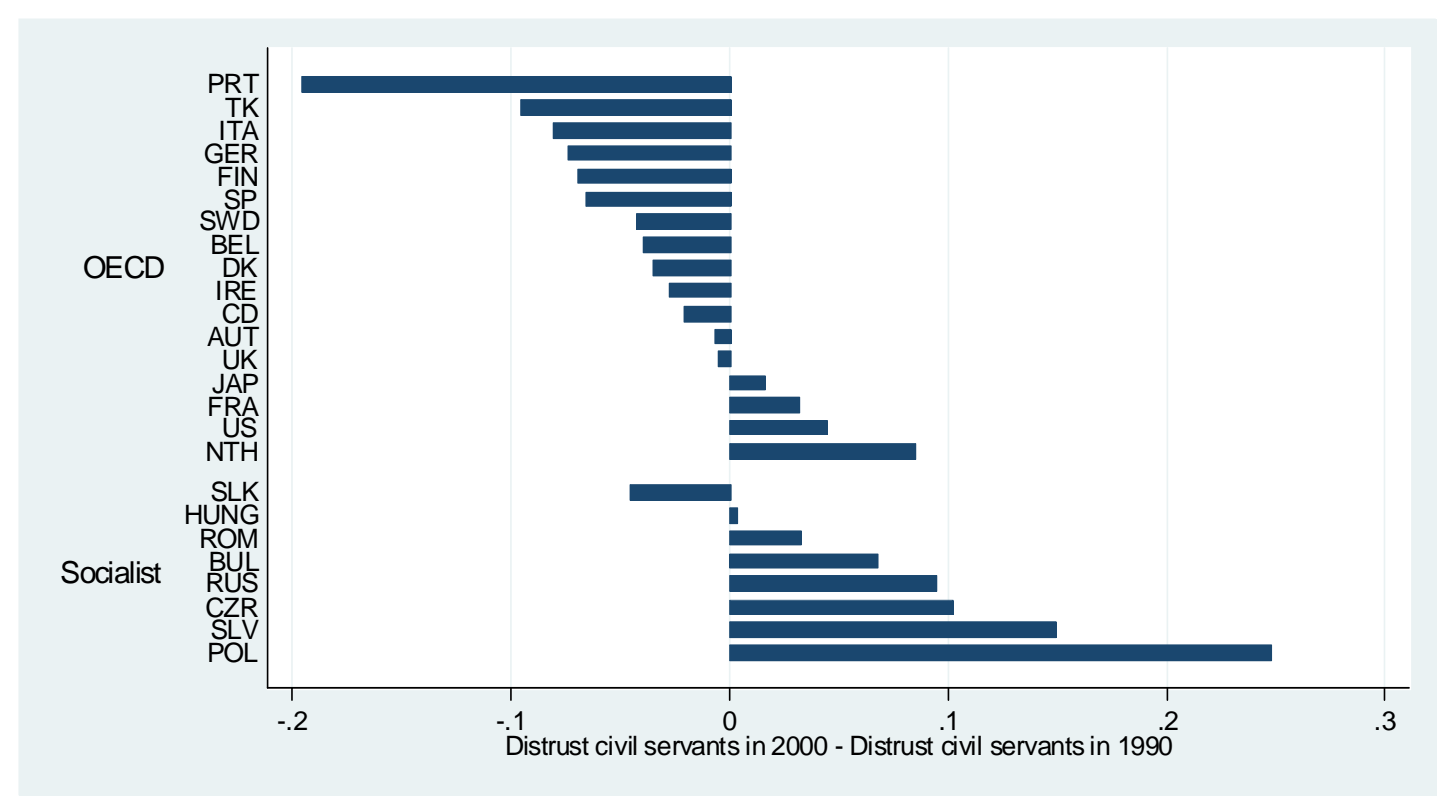

Figure 24: Time-variation in the share of households who distrust civil servants between the wave 2000 and the wave 1990. Source WVS database. 


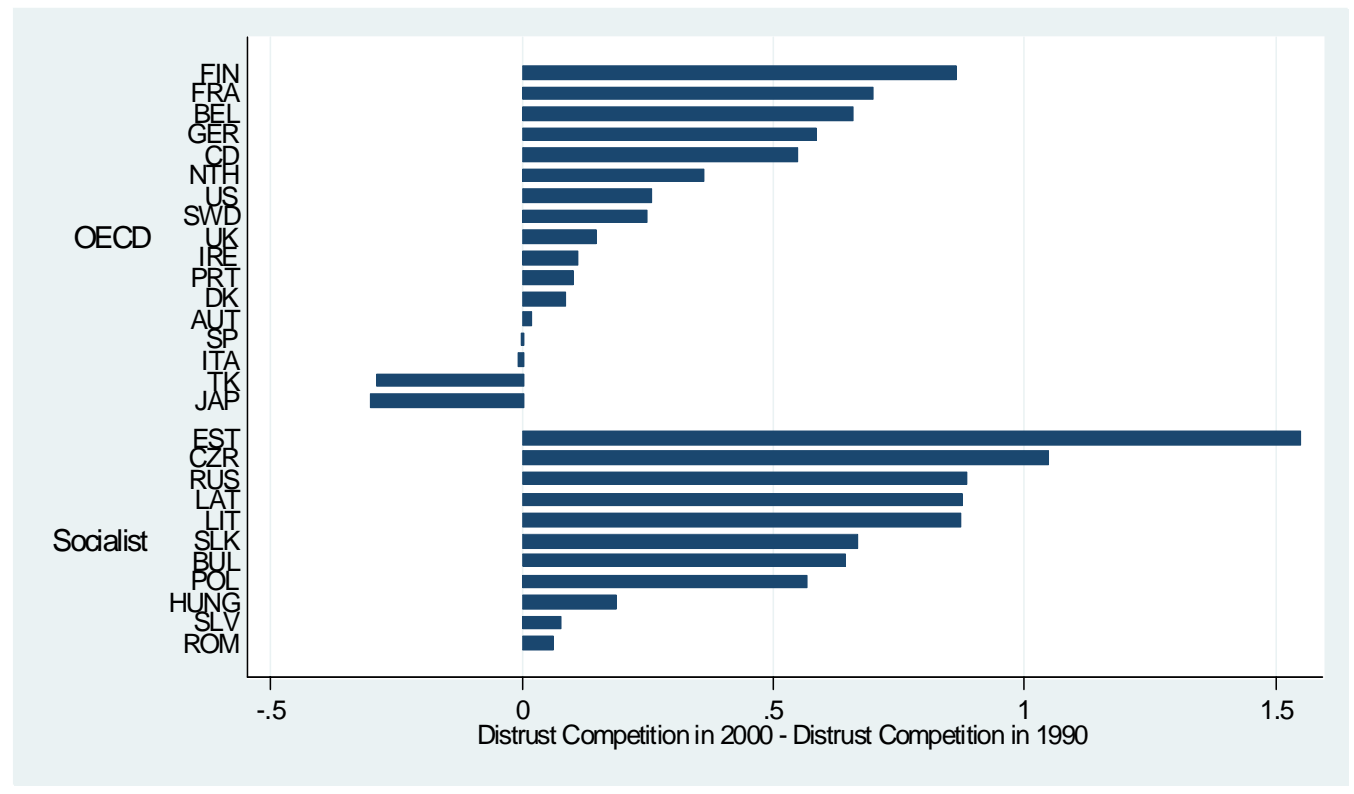

Figure 25: Time-variation in the share of households who consider competition as harmful between the wave 2000 and the wave 1990. Source WVS database.

We also consider the degree of hierarchical relationship within the family with the question: "Regardless of what the qualities and faults of one's parents are, one must always love and respect them". The answer is either "Always respect" or "Respect is earned". The first answer suggests a conception of the family based on authority and vertical relationship. The second answer suggests a family model based on a mutual contract of recognition and respect, promoting horizontal relationships. We create a dummy variable Family_Mutual respect equal to 1 if the respondent answers that respect from a child has to be earned, and zero otherwise.

Figures 26 through 28 show the correlation at the country-level between distrust and the indexes Family_Mutual respect, Educ_Independence and Educ_Tolerance. The figures reveal a strong negative correlation between the extent of distrust in a society and the importance of norms of socialization and tolerance that are transmitted through parents. The R-squared is 0.40, 0.22 and 0.22 for the correlation between distrust and the indicators of Family_Mutual respect, Educ_Independence and Educ_Tolerance respectively.

Table 8 confirms these findings with regressions controlling for per capita income and various indicators of education. Column 1 reports the stripped down regression of distrust on per capita income and the average years of education. Education measured by the average years are only significant at the ten percent level. Column 2 includes the indicator Family_mutual respect measuring education of mutual respect between the parents and the children. The negative 


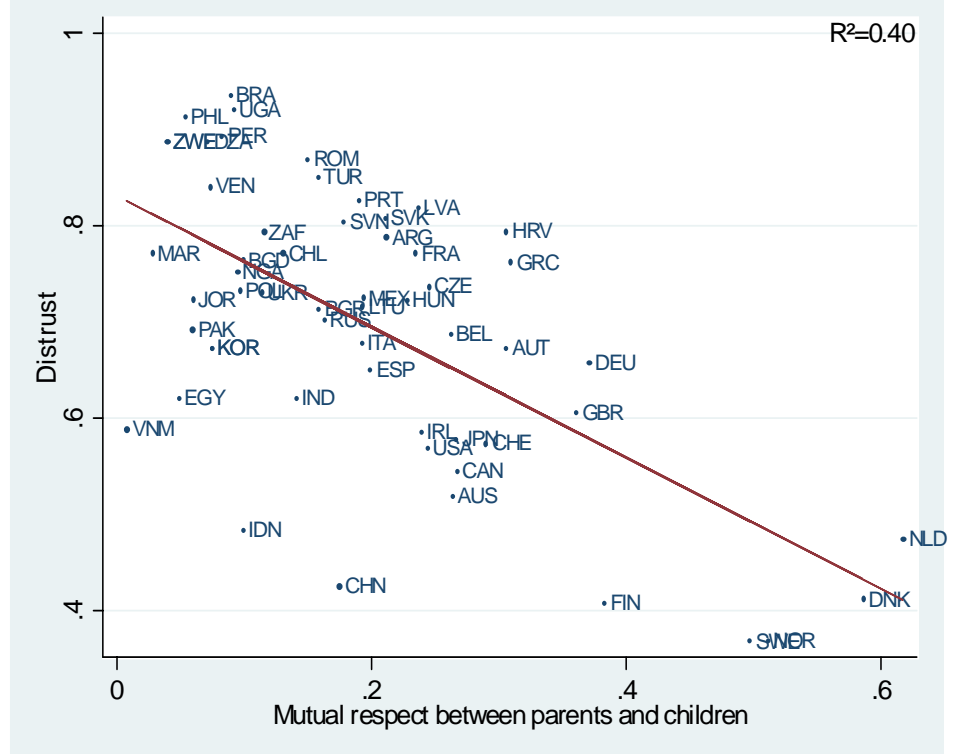

Figure 26: Correlation between the country share of distrust and the share of households who consider that respect from children has to be earned rather than imposed by parents. Source: WVS 1980-2000.

correlation with distrust is statistically significant at the 1 percent level, while the indicator of years of education looses all its statistical power. The same statistically significant relationship holds between distrust and each indicator of civic education taken separately or all together.

\section{Conclusion}

In conclusion, we note two aspects of the problem that were mentioned in the discussion, but not analyzed in any detail. The first is the relationship between our findings and research on legal origins. A number of papers summarized in La Porta et al. (2008) have shown that the very same measures of government regulation that we consider in this paper are predicted by legal origins. This raises the question of the relationship between legal origins and distrust, and their respective influences on regulation. It is easy to show that French legal origin countries, on average, exhibit lower levels of trust than common law and Scandinavian legal origin countries, but is there a deeper relationship here?

Glaeser and Shleifer (2002) argue that France and England developed their legal systems many centuries ago in response to very different levels of disorder prevalent in the two countries, with England being much more peaceful and orderly than France. The two legal traditions were 


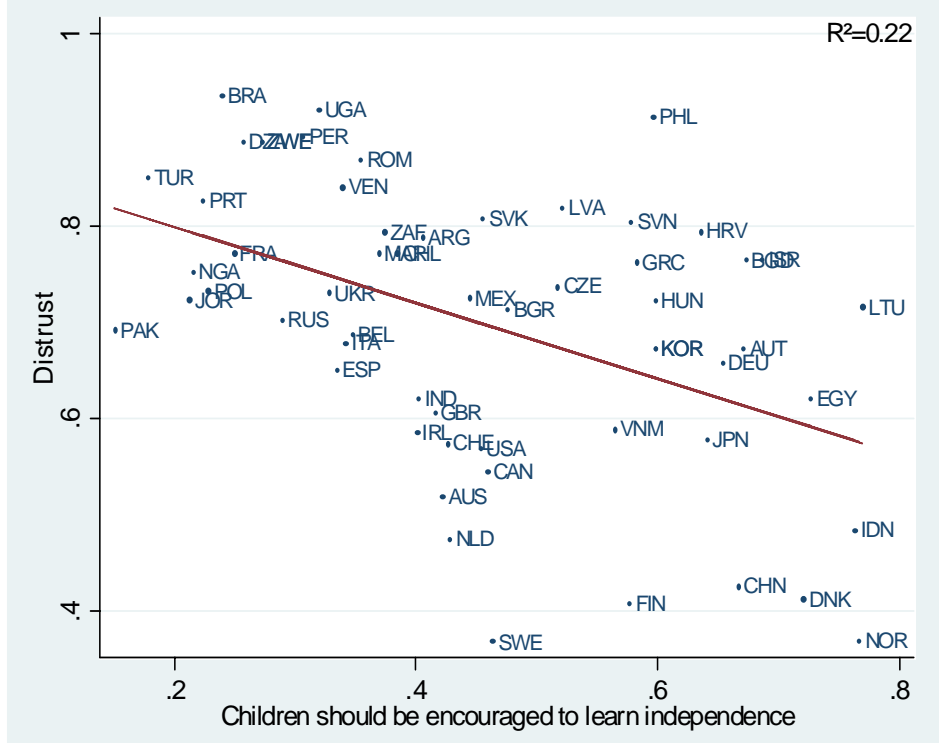

Figure 27: Correlation between the country-share of distrust and the share of parental values in favor of teaching independence to children. Source: WVS 1980 - 2000.

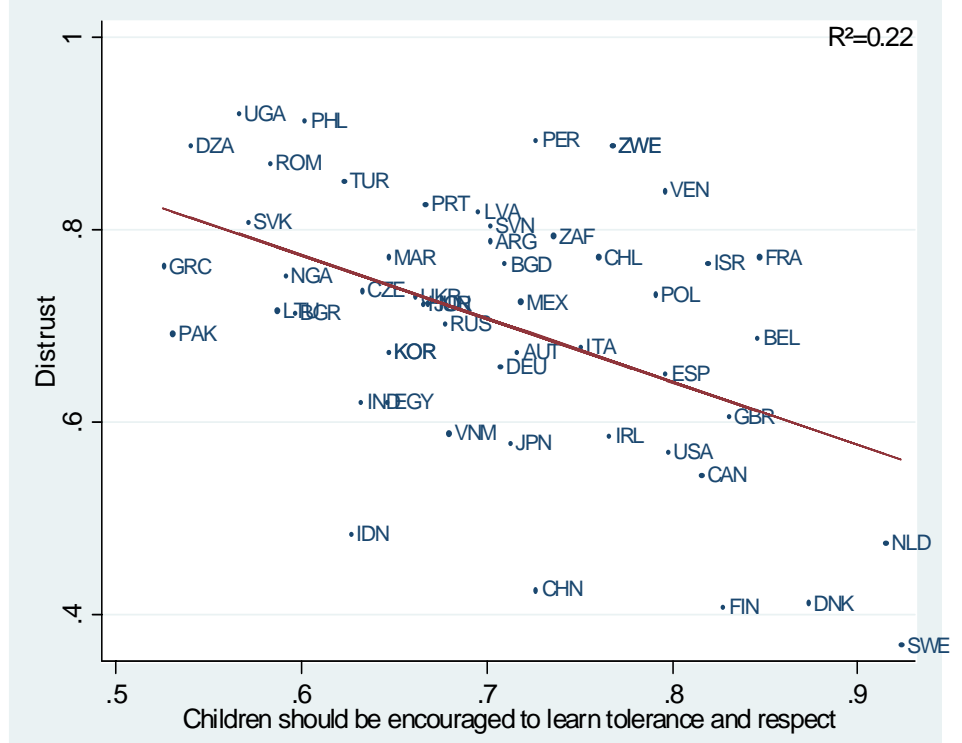

Figure 28: Correlation between the country-share of distrust and the share of parental values in favor of teaching tolerance to children. Source: WVS 1980 - 2000. 
subsequently transplanted through conquest and colonization to many parts of the world, and there is no reason to think that the colonies of the two countries started with different levels of distrust (Nunn and Wantchekon 2008). On the other hand, our paper suggests that, over time, the level of regulation can itself influence investment in social capital. It is possible, then, that compared to the English colonies, the more heavily regulated French colonies over the decades have developed lower levels of trust (because of a more controlling role of the state) and that this lower trust has generated continued demand for government regulation. If this hypothesis is correct, one reason that legal origins have had such a pervasive influence on outcomes over the years might be that their influence is mediated by trust in a self-fulfilling equilibrium. This might be a new explanation for the persistent effects of legal origins.

A second aspect of the problem that deserves some additional attention is our assumption that accumulation of social capital is largely decentralized because it takes place in families. In fact, in our model, if the community can agree on a program of public education that raises the level of social capital, and if this program is successfully implemented, the bad equilibrium is eliminated. It is unquestionably the case that, in some countries, an important goal of public education is to build social capital (Glaeser et al. 2007). But, evidently, this goal is not universal. This observation raises the open question of what are the possibilities and the limits of public education in raising the level of social capital, especially in environments where parents do not share an interest in civility.

More generally, the analysis points to a broad complementarity between social capital and free market economics, which remains to be explored.

\section{References}

[1] Alesina, A. and La Ferrara, E., 2002, Who Trusts Others?, Journal of Public Economics, 85(2):207-304.

[2] Alesina, A., Devleeschauwer, A., Easterly, W., Kurlat, S. and Wacziarg, R., Fractionalization, Journal of Economic Growth, 8:155-194.

[3] Alesina, A. and Glaeser, E., 2004, Fighting Poverty in the US and Europe, Oxford, UK: Oxford University Press.

[4] Alesina, A. and Angeletos, G.-M., 2005a, Fairness and Redistribution, American Economic Review 95(5):960-980. 
[5] Alesina, A. and Angeletos, G.-M., 2005b, Corruption, Inequality, and Fairness, Journal of Monetary Economics, 52:1227-1244.

[6] Alesina, A. and Fuchs-Schündeln, N., 2007, Good-Bye Lenin (or Not?): The Effect of Communism on People's Preferences, American Economic Review, 97(4):1507-1528.

[7] Aghion P., Algan, Y. and Cahuc, P., 2008, Can Policy Influence Culture? Minimum Wage and the Quality of Labor Relations, Harvard Working Paper.

[8] Algan, Y. and Cahuc, P., 2007, Social Attitudes and Economic Development: An Epidemiological Approach, IZA Working Paper n²235.

[9] Banfield, E., 1958, The Moral Basis of a Backward Society, New York, NY: Free Press.

[10] Becker, G., Human Capital: A Theoretical and Empirical Analysis, with Special Reference to Education, 1963, Chicago, IL: University of Chicago Press.

[11] Bisin, A and Verdier, T., 2001, The Economics of Cultural Transmission and the Evolution of Preferences, Journal of Economic Theory, 97(2):298-319.

[12] Bloom, N., Sadun, R. and Van Reenen, J., 2007, The Organization of Firms Across Countries, Stanford University Mimeo.

[13] Botero, J., Djankov, S., La Porta, R., Lopez-de-Silanes, F. and Shleifer, A., 2004, The Regulation of Labor, Quarterly Journal of Economics, 119(4):1339-82.

[14] Carlin, B., Dorobantu, F. and Viswanathan, S., 2007, Public Trust, the Law, and Financial Investment, Working Paper.

[15] Coleman, J., 1990, Foundations of Social Theory, Cambridge, MA: Harvard University Press.

[16] DiTella, R. and McCulloch, R., 2006, Why Doesn't Capitalism Flow to Poor Countries?, Harvard University Mimeo.

[17] Djankov, S., La Porta, R., Lopez-De-Silanes, F. and Shleifer, A., 2002, The Regulation of Entry, Quarterly Journal of Economics, 117(1):1-37.

[18] Djankov, S., La Porta, R., Lopez-de-Silanes, F. and Shleifer, A., 2003a, Courts, Quarterly Journal of Economics, 118(2):453-517.

[19] Djankov, S., Glaeser, E., La Porta, R., Lopez-de-Silanes, F. and Shleifer, A., 2003b, The New Comparative Economics, Journal of Comparative Economics, 31:595-619. 
[20] Easterly, W. and Levine, R., 1997, Africa's Growth Tragedy: Policies and Ethnic Divisions, Quarterly Journal of Economics, 112:1203-1250.

[21] Gambetta, T., 1988, Trust, Making and Breaking Cooperative Relations, Oxford, UK: Blackwell.

[22] Glaeser, E., Laibson, D., Scheinkman, J. and Soutter, C., 2000, Measuring Trust, Quarterly Journal of Economics, 115(3):811-846.

[23] Glaeser, E. and Shleifer, A., 2002, Legal Origins, Quarterly Journal of Economics, 117(4):1193-1229.

[24] Glaeser, E. and Shleifer, A., 2003, The Rise of the Regulatory State, Journal of Economic Literature, 41(2):401-425.

[25] Glaeser, E., Ponzetto, G. and Shleifer, A., 2007, Why Does Democracy Need Education?, Journal of Economic Growth, 12:77-99.

[26] Guiso, L., Sapienza, P. and Zingales, L., 2003, People's Opium? Religion and Economic Attitudes, Journal of Monetary Economics, 50:225-282.

[27] Guiso, L., Sapienza, P. and Zingales, L., 2004, The Role of Social Capital in Financial Development, American Economic Review, 94:526-556.

[28] Guiso, L., Sapienza, P. and Zingales, L., 2006, Does Culture Affect Economic Outcome?, Journal of Economic Perspectives, 20:23-48.

[29] Guiso, L., Sapienza. P. and Zingales, L., 2007a, Long Term Persistence, mimeo, University of Chicago.

[30] Guiso, L., Sapienza, P. and Zingales, L., 2007b, Social Capital as Good Culture, mimeo, University of Chicago.

[31] Gwartney, J., Lawson, R. and Block, W., 1996, Economic Freedom of the World, 1975-1995, The Fraser Institute, Vancouver.

[32] Knack, S. and Keefer, P., 1997, Does Social Capital Have an Economic Payoff, A CrossCountry Comparison, Quarterly Journal of Economics, 112:1251-1288.

[33] Landes, David, 1998, The Wealth and Poverty of Nations. New York, NY: W. W. Norton.

[34] Landier, A., Thesmar, D. and Thoenig, M., 2007, Investigating Capitalism-Aversion, Manuscript. 
[35] La Porta, R., Lopez-de-Silanes, F., Shleifer, A. and Vishny, R., 1997, Trust in Large Organizations, American Economic Review, 87(2):333-38.

[36] La Porta, R., Lopez-de-Silanes, F., Shleifer, A. and Vishny, R., 1999, The Quality of Government, Journal of Law, Economics and Organization, 15(1):222-279.

[37] La Porta, R., Lopez-de-Silanes, F. and Shleifer, A., 2002, Government Ownership of Banks, Journal of Finance, 57(1):265-301.

[38] La Porta, R., Lopez-de-Silanes, F. and Shleifer, A., 2008, The Economic Consequences of Legal Origins, Journal of Economic Literature, 46(2):285-332.

[39] Licht, A., Goldschmidt, C. and Schwartz, S., 2005, Culture, Law, and Corporate Governance, International Review of Law and Economics, 25(2):229-255.

[40] Murphy, K., Shleifer, A. and Vishny, R., 1991, The Allocation of Talent: Implications for Growth, Quarterly Journal of Economics, 106(2):503-530.

[41] Nunn, N. and L. Wantchekon, 2008, The Trans-Atlantic Slave Trade and the Evolution of Mistrust in Africa: An Empirical Investigation, Mimeo.

[42] Putnam, R., 1993, Making Democracy Work, Princeton, NJ: Princeton University Press.

[43] Shleifer, A., 1997, Government in Transition, European Economic Review, 41(3-5):385-410.

[44] Shleifer, A. and Triesman, D., 2005, A Normal Country, Journal of Economic Perspectives, 19(1):151-174.

[45] Stulz, R. and Williamson, R., 2003, Culture, Openness, and Finance, Journal of Financial Economics, 70(3):313-349.

[46] Tabellini, G., 2005, Culture and Institutions: Economic Development in the Regions of Europe, IGIER working paper.

[47] Tabellini, G., 2007a, The Scope of Cooperation: Norms and Incentives, IGIER working paper.

[48] Tabellini, G., 2007b, Culture and Institutions, IGIER working paper.

\section{Appendix}


Table 1: Distrust and Regulation: OLS estimates

\begin{tabular}{|c|c|c|c|}
\hline Dependent variable & $\begin{array}{l}\text { Regulation } \\
\text { of product market } \\
(1)\end{array}$ & $\begin{array}{l}\text { Regulation of labor } \\
\text { market } \\
(2)\end{array}$ & $\begin{array}{l}\text { Court formalism } \\
\text { index } \\
(3)\end{array}$ \\
\hline \multicolumn{4}{|c|}{ Panel A - Distrust and regulation } \\
\hline Distrust in others & $\begin{array}{l}1.695^{* * *} \\
(.4283)\end{array}$ & $\begin{array}{l}.5306^{* * *} \\
(.176)\end{array}$ & $\begin{array}{l}2.922^{* * *} \\
(.790)\end{array}$ \\
\hline Ln (GDP & -.0537 & .002 & .0343 \\
\hline per capita) & $(.056)$ & $(.023)$ & $(.102)$ \\
\hline Education & $\begin{array}{l}-.046 \\
(.031)\end{array}$ & $\begin{array}{l}-.001 \\
(.012)\end{array}$ & $\begin{array}{l}-.0372 \\
(.058)\end{array}$ \\
\hline Observations & 56 & 56 & 55 \\
\hline $\mathrm{R}^{2}$ & .44 & .139 & .25 \\
\hline \multicolumn{4}{|c|}{ Panel B - Lack of civic spirit and regulation } \\
\hline Uncivic & $\begin{array}{l}.943^{* *} \\
(.448)\end{array}$ & $\begin{array}{l}.365^{* *} \\
(.176)\end{array}$ & $\begin{array}{l}1.635^{* *} \\
(.767)\end{array}$ \\
\hline Ln (GDP & -.085 & -.0110 & -.0765 \\
\hline per capita) & $(.061)$ & $(.0241)$ & $(.105)$ \\
\hline Education & $\begin{array}{l}-.092^{* * *} \\
(.034)\end{array}$ & $\begin{array}{l}-.011 \\
(.013)\end{array}$ & $\begin{array}{l}-.076 \\
(.059)\end{array}$ \\
\hline Observations & 50 & 50 & 50 \\
\hline $\mathrm{R}^{2}$ & .36 & .07 & .14 \\
\hline
\end{tabular}


Table 2: Distrust in Business, Institutions and Regulation: OLS estimates

\begin{tabular}{|c|c|c|c|}
\hline Dependent variable & $\begin{array}{l}\text { Regulation } \\
\text { of product market } \\
(1)\end{array}$ & $\begin{array}{l}\text { Regulation of labor } \\
\text { market } \\
(2)\end{array}$ & $\begin{array}{l}\text { Court formalism } \\
\text { index } \\
(3)\end{array}$ \\
\hline \multicolumn{4}{|c|}{ Panel A - Distrust in business and regulation } \\
\hline Distrust in & $1.881^{* * *}$ & $.528^{* *}$ & $2.646^{* * *}$ \\
\hline major companies & $(.638)$ & $(.239)$ & $(1.180)$ \\
\hline Ln (GDP & -.050 & .016 & -.000 \\
\hline per capita) & $(.062)$ & $(.023)$ & $(.115)$ \\
\hline \multirow{2}{*}{ Education } & $-.085^{* *}$ & .020 & -.067 \\
\hline & $(.035)$ & $(0.13)$ & $(.065)$ \\
\hline Observations & 48 & 48 & 48 \\
\hline $\mathrm{R}^{2}$ & .40 & .12 & .12 \\
\hline \multicolumn{4}{|c|}{ Panel B - Distrust in unions and regulation } \\
\hline Distrust in & $1.309^{* *}$ & $.526^{* *}$ & $3.749^{* * *}$ \\
\hline unions & $(.590)$ & $(.227)$ & $(.940)$ \\
\hline Ln (GDP & -.078 & -.016 & -.081 \\
\hline per capita) & $(.064)$ & $(.023)$ & $(.096)$ \\
\hline \multirow{2}{*}{ Education } & $-.080^{* *}$ & -.004 & -.024 \\
\hline & $(.037)$ & $(.013)$ & $(.055)$ \\
\hline Observations & 50 & 50 & 50 \\
\hline $\mathrm{R}^{2}$ & .35 & .15 & .25 \\
\hline \multicolumn{4}{|c|}{ Panel C - Distrust in the Legal system and Regulation } \\
\hline Distrust in & $2.964^{* * *}$ & $.780^{* *}$ & $5.790^{* * *}$ \\
\hline justice & $(.804)$ & $(.323)$ & $(1.274)$ \\
\hline Ln (GDP & -.018 & -.004 & .055 \\
\hline per capita) & $(.062)$ & $(.025)$ & $(.099)$ \\
\hline \multirow{2}{*}{ Education } & $-.078^{* *}$ & -.003 & -.043 \\
\hline & $(.034)$ & $(.013)$ & $(.055)$ \\
\hline Observations & 45 & 45 & 45 \\
\hline $\mathrm{R}^{2}$ & .41 & .10 & .30 \\
\hline \multicolumn{4}{|c|}{ Panel D - Distrust in Parliament and Regulation } \\
\hline Distrust in & $1.356^{* *}$ & $.645^{* * *}$ & $3.235^{* * *}$ \\
\hline parliament & $(.551)$ & $(.207)$ & $(.920)$ \\
\hline Ln (GDP & $-.077^{* *}$ & -.010 & -.042 \\
\hline per capita) & $(.059)$ & $(.022)$ & (.099) \\
\hline & $-.063^{*}$ & .001 & -.008 \\
\hline Education & $(.035)$ & $(.013)$ & $(.058)$ \\
\hline Observations & 50 & 50 & 50 \\
\hline $\mathrm{R}^{2}$ & .36 & .17 & .20 \\
\hline
\end{tabular}


Table 3: Distrust and Regulation: Robustness checks

\begin{tabular}{llll}
\hline \hline Dependent variable & \multicolumn{3}{l}{ Regulation of product market } \\
\hline \multirow{4}{*}{$\begin{array}{l}\text { (1) } \\
\text { Distrust others }\end{array}$} & $1.087^{* *}$ & & \\
& $(.439)$ & & \\
& & $.851^{*}$ & \\
Distrust civil servants & & $(.435)$ & \\
& & & $1.452^{* * *}$ \\
Distrust companies & & & $(.512)$ \\
Ln (GDP & -.045 & -.060 & -.118 \\
per capita) & $(.091)$ & $(.111)$ & $(.111)$ \\
& $-.076^{* *}$ & $-.105^{* *}$ & $-.102^{* *}$ \\
Education & $(.038)$ & $(.040)$ & $(.038)$ \\
& -.012 & -.022 & -.000 \\
Democracy & $(.025)$ & $(.029)$ & $(.029)$ \\
& -.205 & -.192 & -.431 \\
Fractionalization & $(.334)$ & $(.368)$ & $(.371)$ \\
$\mathrm{R}^{2}$ & .530 & .504 & .551 \\
\hline Observations & 43 & 41 & 40 \\
\hline
\end{tabular}

Table 4: Distrust and demand for regulation: Micro estimates - Ordered probit

\begin{tabular}{|c|c|c|c|c|}
\hline $\begin{array}{l}\text { Explanatory variables (Columns) } \backslash \\
\text { Independent variables (Rows) }\end{array}$ & $\begin{array}{l}\begin{array}{l}\text { Distrust } \\
\text { others }\end{array} \\
\text { othen }\end{array}$ & $\begin{array}{l}\text { Distrust legal } \\
\text { system }\end{array}$ & $\begin{array}{l}\text { Distrust civil } \\
\text { servants }\end{array}$ & $\begin{array}{l}\text { Distrus } \\
\text { compa }\end{array}$ \\
\hline (1) Competition is harmful & $\begin{array}{l}.027^{* * *} \\
(.010)\end{array}$ & $\begin{array}{l}.025^{* * *} \\
(.007)\end{array}$ & $\begin{array}{l}.013^{* *} \\
(.006)\end{array}$ & $\begin{array}{l}.139^{3} \\
(.006\end{array}$ \\
\hline $\mathrm{N}$ & 114722 & 93406 & 111113 & \\
\hline $\begin{array}{l}\text { (2) Government should } \\
\text { take more responsibility }\end{array}$ & $\begin{array}{l}.039^{* * *} \\
(.006)\end{array}$ & $\begin{array}{l}.018^{* *} \\
(.006)\end{array}$ & $\begin{array}{l}.015^{* *} \\
(.006)\end{array}$ & $\begin{array}{l}.088^{3} \\
(.006\end{array}$ \\
\hline $\mathrm{N}$ & 129393 & 123798 & 123798 & 120 \\
\hline $\begin{array}{l}\text { (3) In democracies the economic } \\
\text { system runs badly }\end{array}$ & $\begin{array}{l}.134^{* * *} \\
(.009)\end{array}$ & $\begin{array}{l}.081^{* * *} \\
(.010)\end{array}$ & $\begin{array}{l}.082^{* * *} \\
(.008)\end{array}$ & $\begin{array}{l}.053^{*} \\
(.009\end{array}$ \\
\hline $\mathrm{N}$ & 76061 & 47542 & 74288 & 65 \\
\hline
\end{tabular}

Source: WVS - Controls: country fixed effects, gender, age, education, income, political affiliation Robust standard error with clustering at the country level. ***:1\%, **: 5\%, *: 10. 
Table 5: Initial distrust in transition economies relatively to OECD countries- Marginal Probit estimates

\begin{tabular}{clccc}
\hline \hline Dependent variable & $\begin{array}{l}\text { Distrust } \\
\text { others } \\
(1)\end{array}$ & $\begin{array}{l}\text { Distrust } \\
\text { civil servants } \\
(2)\end{array}$ & $\begin{array}{l}\text { Distrust } \\
\text { Justice } \\
(3)\end{array}$ & $\begin{array}{l}\text { Distrust } \\
\text { companies } \\
(4)\end{array}$ \\
\hline $\begin{array}{c}\text { Transition economies } \\
\text { in } 1990\end{array}$ & $.169^{* * *}$ & $.055^{*}$ & $.063^{* *}$ & $.151^{* * *}$ \\
$\mathrm{R}^{2}$ & $(.033)$ & $(.033)$ & $(.032)$ & $(.046)$ \\
Observations & .054 & 011 & .015 & .020 \\
\hline
\end{tabular}

Controls: gender, age, education, income, political affiliation.

Source: WVS survey. Robust standard errors : ***:1\%, **: 5\%, *: 10.

Table 6: Deregulation and Demand for regulation: Micro evidence from Transition Economies

\begin{tabular}{|c|c|c|}
\hline & $\begin{array}{l}\text { Competition is } \\
\text { harmful }(1-10) \\
\text { (1) }\end{array}$ & $\begin{array}{l}\text { Owners should run } \\
\text { their business }(1-0) \\
\text { (2) }\end{array}$ \\
\hline Wave 2000 & $.147^{* * *}$ & $-.121^{* * *}$ \\
\hline $\begin{array}{l}\text { Transition economies } \mathrm{x} \\
\text { wave } 2000\end{array}$ & $\begin{array}{l}.232^{* * *} \\
(.016)\end{array}$ & $\begin{array}{l}.013^{* *} \\
(.006)\end{array}$ \\
\hline $\mathrm{R}^{2}$ & .017 & .019 \\
\hline $\begin{array}{l}\text { Wald test : Wave } 1996 \text { - } \\
\text { Transitions x Wave } 1996\end{array}$ & $\begin{array}{l}\text { Prob }>\chi^{2}(1)= \\
0.000\end{array}$ & $\begin{array}{l}\text { Prob }>\chi^{2}(1)= \\
0.000\end{array}$ \\
\hline Observations & 67012 & 36247 \\
\hline
\end{tabular}


Table 7: Regulation and Distrust : Micro evidence from Transition Economies - Marginal Probit estimates

\begin{tabular}{ccccc}
\hline \hline Dependent variable & $\begin{array}{l}\text { Distrust } \\
\text { in others }\end{array}$ & $\begin{array}{l}\text { Distrust in } \\
\text { civil servants }\end{array}$ & $\begin{array}{l}\text { Distrust in } \\
\text { Justice }\end{array}$ & $\begin{array}{c}\text { Distrust in } \\
\text { companies }\end{array}$ \\
\hline Wave 2000 & .036 & $-.034^{* *}$ & .020 & $.039^{* * *}$ \\
& $(.027)$ & $(.025)$ & $(.034)$ & $(.006)$ \\
Transition economies x & $.058^{*}$ & $.122^{* * *}$ & $.114^{* * *}$ & $.098^{* * *}$ \\
Wave 2000 & $(.033)$ & $(.035)$ & $(.038)$ & $(.015)$ \\
Wald test : Wave 2000 - & Prob $>\chi^{2}(1)=$ & Prob $>\chi^{2}(1)$ & $\begin{array}{c}\text { Prob }>\chi^{2}(1) \\
=0.098\end{array}$ & $\begin{array}{c}\text { Prob }>\chi^{2}(1) \\
=0.002\end{array}$ \\
Transition x Wave 2000 & 0.70 & 0.000 & .051 & .085 \\
$\mathrm{R}^{2}$ & .0819 & 041 & & \\
Observations & 55015 & 56014 & 48989 & 56664 \\
\hline
\end{tabular}

WVS - Controls: country fixed effects, gender, age, education, income, political affiliation.

Robust standard errors : **:1\%, **: $5 \%, *: 10$.

Table 8: Parental values and Distrust: OLS estimates

\begin{tabular}{lccccl}
\hline \hline Dependent variable & \multicolumn{5}{c}{ Distrust in others } \\
Education & $-.017^{*}$ & -.009 & -.006 & -.007 & .000 \\
& $(.009)$ & $(.008)$ & $(.009)$ & $(.009)$ & $(.008)$ \\
Family_Mutual respect & & $-.664^{* * *}$ & & & $-.422^{* * *}$ \\
& & $(.164)$ & & & $(.163)$ \\
Educ_independence & & & $-.309^{* * *}$ & & $-.316^{* * *}$ \\
& & & $(.100)$ & & $(.092)$ \\
Educ_Tolerance & & & & $-.511^{* * *}$ &.$- .502^{* * *}$ \\
Ln (GDP & -.015 & .012 & -.026 & -.006 & -.006 \\
per capita) & $(.009)$ & $(.017)$ & $(.016)$ & $(.018)$ & $(.018)$ \\
Observations & 55 & 55 & 55 & 52 & 52 \\
$\mathrm{R}^{2}$ & .22 & .41 & .34 & .34 & .53 \\
\hline
\end{tabular}


Table 9: Variable definitions

Share of people who answer "need to very careful in dealing with people" to the question: "Generally speaking, would you say that

Distrust most people can be trusted or that you need to be very careful in dealing with people?". We measure the average country level of distrust over three waves of the WVS database in 1980, 1990 and 2000

Share of people who do not answer "never justifiable" to the question: "Do you think it is unjustifiable or not to cheat on

Uncivic government benefits". The answers ranges from 1 for never justifiable to 10 for always justifiable. We calculate the country-share of respondents who answers never justifiable averaged over the three waves of the WVS database in 1980, 1990 and 2000

Share of people who answer "no confidence" to the question: "Do you have confidence in major companies".

Distrust in The answers range from 1 for a lot companies of confidence to 4 for no confidence. We calculate the average country-share of respondents who answers no confidence over the three waves of the WVS database in 1980, 1990 and 2000

Share of people who answer "no confidence" to the question: "Do you have a lot of confidence, not very much confidence,

Distrust in unions no confidence in labor unions". The answers range from 1 for a lot of confidence to 4 for no confidence. We calculate the average country share of respondents who answers no confidence over the three waves of the WVS database in 1980, 1990 and 2000

Share of people who answer "no confidence" to the question:

"Do you have confidence in the legal system". The answers range

Distrust in from 1 for a lot of confidence to 4 for no confidence.

legal system

We calculate the average country share of respondents who answers no confidence over the three waves of the WVS database in 1980,1990 and 2000

Share of people who answer "no confidence" to the question: "Do you have confidence in the parliament".

Distrust in The answers range from 1 for a lot of confidence to 4

parliament for no confidence. We calculate the average country share of respondents who answers no confidence over the three waves of the WVS database in 1980, 1990 and 2000 
Table 10: Variable definition

\begin{tabular}{lll}
\hline \hline Variables & \multicolumn{1}{c}{ Description } & $\mathrm{N}$ \\
& & Countries \\
\hline & $\begin{array}{l}\text { Individual questions on regulation } \\
\text { and education }\end{array}$ & \\
\hline
\end{tabular}

Country average score to the question: "Do you think that the

State should state should give complete freedom to the firm or that the control firms state should control firm". The answers range from 1 for complete freedom to 10 for complete control. The score is averaged over the three waves of the WVS database in 2000

Share of respondents who answer yes to the question: "Do

Economic system runs badly under a democracy

Education: tolerance and respect for other people

Education: Independence you think that the economic system runs necessarily badly under a democracy". The indicator equal one if the respondent answers yes and 0 if the answer is no. The indicator is averaged over the three waves of the WVS database in 1980, 1990 and 2000

Share of respondents who answer "especially important" to the question "Here is a list of qualities which children can be encouraged to learn at home. Which if any do you consider to be especially important: Tolerance and Respect for other people". The indicator equal 1 if the answer is "especially important", and 0 if the answer is "not important". The indicator is averaged over the three waves of the WVS database in 1980,1990 and 2000

Share of respondents who answer "especially important" to the question: "Here is a list of qualities which children can be encouraged to learn at home. Which if any do you consider to be especially important:Independence". The indicator equal 1 if the answer is "especially important", and 0 if the answer is "not important". The indicator is averaged over the three waves of the WVS database in 1980, 1990 and 2000 
Table 11: Variable definition

\begin{tabular}{|c|c|c|}
\hline Variables & Description & $\begin{array}{l}\mathrm{N} \\
\text { Countries }\end{array}$ \\
\hline \multicolumn{3}{|c|}{ Other variables } \\
\hline $\begin{array}{l}\text { Log of GNP } \\
\text { per capita }\end{array}$ & $\begin{array}{l}\text { Natural logarithm of GNP per capita in 1997, Atlas method, } \\
\text { expressed in current US dollars. Source: World Bank, } \\
\text { World Development Indicators (2001). }\end{array}$ & 56 \\
\hline Legal origin & $\begin{array}{l}\text { Identifies the legal origin of the company law or commercial } \\
\text { code of each country (English, French, Socialist, German } \\
\text { or Scandinavian). Source: La Porta et al. (2008). }\end{array}$ & 56 \\
\hline $\begin{array}{l}\text { Average years of } \\
\text { schooling }\end{array}$ & $\begin{array}{l}\text { Years of schooling of the total population aged over } 25, \\
\text { average of } 1995 \text { and } 2000 . \text { Source: Barro and Lee }(2000) \\
\text { <http://www.cid.harvard.edu/ciddata/ciddata.htm>. }\end{array}$ & 56 \\
\hline $\begin{array}{l}\text { Ethnolinguistic } \\
\text { fractionalization }\end{array}$ & $\begin{array}{l}\text { The index measures the probability that two randomly } \\
\text { selected people from a given country will not belong to the same } \\
\text { ethnolinguistic group. The index is based on the number and size } \\
\text { of population groups as distinguished by their ethnic and linguistic } \\
\text { status. Source: Easterly and Levine, (1997). }\end{array}$ & 56 \\
\hline $\begin{array}{l}\text { Hierarchical } \\
\text { religions }\end{array}$ & $\begin{array}{l}\text { The index measures the share of people belonging to hierarchical } \\
\text { religions: Catolic, Eastern Orthodox and Muslim religions } \\
\text { Source: La Porta et al. (1997) and Barro's webpage. }\end{array}$ & 35 \\
\hline $\begin{array}{l}\text { Regulation } \\
\text { of good market }\end{array}$ & $\begin{array}{l}\text { The index measures the (ln) number of steps in order to open } \\
\text { a business in 1999. Source: Djankov et al. (2002). }\end{array}$ & 56 \\
\hline $\begin{array}{l}\text { Regulation } \\
\text { of labor market }\end{array}$ & $\begin{array}{l}\text { The index measures the rigidity of employment contracts } \\
\text { in 1999, based on i) difficulty of hiring, ii) rigidity of } \\
\text { hours, iii) difficulty of firing. Source: Botero et al. (2004). }\end{array}$ & 56 \\
\hline $\begin{array}{l}\text { Court formalism } \\
\text { index }\end{array}$ & $\begin{array}{l}\text { The index measures substantive and procedural statutory } \\
\text { intervention in a case for evicting a tenant that has not paid rent } \\
\text { or to collect a bounced check. Source: Djankov et al. (2003). }\end{array}$ & 55 \\
\hline
\end{tabular}

